\title{
O DIREITO DE RECESSO NO DIREITO BRASILEIRO E NA LEGISLAÇÃO COMPARADA*
}

\author{
Newton De Lucca \\ Professor Associado do Departamento de Direito Comercial \\ da Faculdade de Direito da Universidade de São Paulo
}

\begin{abstract}
Resumo:
Versa o presente trabalho sobre o direito de recesso no Direito brasileiro, com ligeiras incursões na legislação comparada acerca da matéria. Após as necessárias considerações introdutórias sobre o enquadramento do tema e acerca da análise que se pretendeu desenvolver, passou-se a examinar o conceito e a função do direito de recesso, seguindo-se com o breve cotejo da legislação comparada. Alude-se, em rápidas linhas, ao direito de recesso na sociedade por cotas de responsabilidade limitada, para se chegar, depois, à Lei n. 6.404/76, disciplinadora das sociedades por ações no Brasil. Embora já expressamente revogada, a Lei n. 7.958/89 — alcunhada "Lei Lobão" — não poderia deixar de ter sido analisada em razăo da enorme celeuma por ela causada no mundo jurídico. Finalmente, embora de forma sintética, foram referidas as modificações operadas sobre o direito de recesso com o advento da recente Lei n. 9.457/97, tendo em conta a política macroeconômica do Governo Federal com as privatizações. Concluiu-se a presente exposição com bibliografia especializada sobre a matéria versada.
\end{abstract}

\begin{abstract}
:
This work refers to the right to withdraw afforded to the dissenting shareholder or quotaholder by Brazilian law, and also presents some considerations about the theme in comparative law. After a preliminary presentation of the subject and of the analysis we intend to develop, the concept and function of the right to withdraw are examined. Further, we present a brief collation of comparative law. In a few lines, we address the right to withdraw in a Brazilian counterpart of the limited liability company, and then examine that right under Law n. 6.404/76, Brazilian corporate law. Though expressly revoked, we also examine Law n. 7.958/89 (also known as "Lobão Law". after the Congressman who proposed the respective bill), due to the great amount of divergence it caused in Brazilian legal community. Finally, although synthetically, we mention the modifications occurred in the right to withdraw as a result of the advent of recent Law n. 9.457/97, enacted within the Federal Government macroeconomical policy regarding the
\end{abstract}

- Texto básico da palestra proferida em Curso sobre Direito Societário promovido pela Faculdade de Direito da Pontifícia Universidade Católica de São Paulo, no dia 09 de novembro de 1998. 
privatization process. As a conclusion, a specialized bibliography about the explained subject is presented.

Unitermos: direito de recesso; legislação comparada; sociedade por cotas de responsabilidade limitada; leis vinculadas ao direito de recesso.

Sumário:

I. Considerações introdutórias. II. Conceito e função do direito de recesso. III. O direito de recesso na legislação comparada. IV $O$ direito de recesso na sociedade por cotas de responsabilidade limitada. V. O direito de recesso na Lei n. 6.404/76. VI. O direito de recesso na Lei n. $7.958 / 89$ (a malfadada "Lei Lobão"). VII. O direito de recesso na Lei n. 9.457/97. VIII. Bibliografia.

\section{Considerações introdutórias.}

Discorrer sobre o direito de recesso, ainda que de forma meramente panorâmica, nos limites de uma única palestra, constitui um daqueles desafios que só podem empolgar os mais corajosos. Espíritos não-afeitos à audácia ou à astúcia, incapazes de empreendimentos difíceis ou que estejam além de suas próprias forças - como há de ser lastimavelmente o meu — não são os mais indicados para tal tarefa...

Reconheço que, no presente caso, tentei reunir toda a audácia que ainda me restava para tentar levar a cabo essa empresa, sem perder de vista, por certo, aquela sábia advertência, atribuída a Lord Chesterfield, de que a astúcia parece ser o sombrio santuário da incapacidade ${ }^{1} \ldots$

Com efeito, há que se ter, sobretudo, para tema tão-vasto a ser enfrentado em algumas poucas horas, um sentido espantoso de resposta às interrogações de natureza mais complexa, além de um poder, deveras especial e quase sempre raro em nosso meio, de captação imediata do âmago das coisas.

Tantos são os aspectos polêmicos desse direito e tantas são as matérias que poderiam ou deveriam ser tratadas por quem se proponha a dissertar sobre elas,

1. Dentre tantas frases de espírito a esse autor atribuídas, tomamos a liberdade de relembrar mais esta: "A única coisa que desejo quanto ao meu enterro é não ser enterrado vivo. 
que o talento para sintetizá-las há de estar, efetivamente, muito além do que o simples esforço deste expositor pode oferecer.

De toda sorte, a maior de todas as coragens, como já se disse algures, é a de assumir responsabilidades. E a esta última, por razões de variada ordem, eu não desejava me esgueirar à sorrelfa, posto ser grande e antigo o meu carinho pela Pontifícia Universidade Católica de São Paulo, que organiza este curso.

Principio por dizer que o art. 109 da Lei n. 6.404, de 15 de dezembro de 1976, disciplinadora das sociedades por ações no Brasil, estabeleceu os chamados direitos essenciais — também conhecidos por direitos intangíveis, fundamentais ou inderrogáveis ${ }^{2}$ — do acionista.

Dispõe ele que:

"Nem o estatuto social nem a assembléia geral poderão privar o acionista dos direitos de:

I-participar dos lucros sociais;

II - participar do acervo da companhia, em caso de liqüidação;

III - fiscalizar, na forma prevista nesta Lei, a gestão dos negócios sociais;

IV - preferência para subscrição de ações, partes beneficiárias conversíveis em ações, debêntures conversíveis em ações e bônus de subscrição, observado o disposto nos arts. 171 e 172;

$V$ - retirar-se da sociedade nos casos previstos nesta Lei.

$\S 1^{\circ}$ As ações de cada classe conferirão iguais direitos aos seus titulares.

$\S 2^{\circ}$ Os meios, processos ou ações que a lei confere ao acionista para assegurar os seus direitos não podem ser elididos pelo estatuto ou pela assembléia geral"

Verifica-se, pois, numa primeira aproximação com o tema, que o direito de recesso se insere no âmbito desses direitos essenciais ou intangíveis, consoante a expressa disposição do inciso $\mathrm{V}$ do art. 109 retrotranscrito. ${ }^{3}$

2. Segundo as Cortes de Justiça norte-americanas, constituem vested rights aquelas prerrogativas dos acionistas que não podem ser derrogadas.

3. Sobre a insuficiência e os perigos de tal inserção, cf. logo mais adiante no texto principal. 
Assim como, no plano constitucional, foram criados os direitos e garantias individuais ${ }^{4}$ quanto à forma de coartar os abusos de poder dos governantes, poder-se-ia dizer, analogamente, que os direitos essenciais do acionista, em certo sentido, foram declarados para conter os atos de abuso de poder por parte dos controladores, consoante vislumbrado por Luis Gastão Paes de Barros Leães: ${ }^{5}$

"Assim, à semelhança dos direitos individuais dos cidadãos, cuja inviolabilidade é assegurada pela Constituição Federal (art. 153), ${ }^{6}$ a Lei de Sociedades Anônimas firma o elenco dos direitos essenciais dos acionistas, assegurando-lhe a intangibilidade, de maneira expressa e taxativa. Esses direitos, somados a poderes, ônus e obrigações atinentes aos acionistas, compõem o chamado status socii, que se define como a posição do sócio dentro da coletividade social, e pressuposto comum e constante de tais direitos e deveres."

Na mesma linha, doutrina José Rubens Costa, ${ }^{7}$ in verbis:

"...Se é certo que os direitos individuais do cidadão decorrem do Direito Natural, não menos certo é que a noção de Direito Natural é muito imprecisa e necessita, por conseguinte, de uma regulamentação de Direito Positivo, para que se determine quais são estes direitos naturais inerentes à condição humana. Da mesma forma, portanto, o Direito Positivo cataloga os direitos essenciais de cada acionista dentro da sociedade, como inerentes à sua condição, ao seu 'status' de sócio."

4. A doutrina constitucionalista distingue, com razão, os direitos individuais das garantias individuais, conforme já apregoara o nosso grande publicista da primeira República, Rui Barbosa ("A Constituição e os Atos Inconstitucionais", Rio de Janeiro, $2^{\mathrm{a}}$ ed., p. 189). Mais modernamente, engendrada como modalidade autônoma, mas decorrente das garantias constitucionais mencionadas, fala-se em garantias institucionais cujo estudo aprofundado é devido ao jurista alemão Carl Schmitt. Para uma ampla e percuciente investigação, entre nós, cf. Paulo Bonavides, "Curso de Direito Constitucional", $6^{\mathbf{a}}$ ed., Malheiros, Capítulo 15, pp. 481 e ss.

5. "Comentários à Lei das Sociedades Anônimas", Saraiva, 1980, §214, p. 216.

6. O autor referiu-se, evidentemente, à Constituição Federal vigente à epoca em que foram escritos os seus Comentários (CF de 1967, com a redação da Emenda Constitucional de 1969). A referência atual seria, como se sabe, ao art. $5^{\circ}$

7. "Sociedades anônimas. Direitos essenciais dos acionistas", Revista Forense 270-567, n. 2, 1980. 
As expressões numa primeira aproximação com o tema e em certo sentido, linhas atrás utilizadas, denotam a nossa preocupação de, independentemente de maiores aprofundamentos doutrinários, prefixarem-se conceitos rígidos e peremptórios, de ranço marcadamente positivista, sem margem às construções exegéticas de qualquer espécie...

Tal procedimento, na verdade, nos parece extremamente nefasto pelo seu caráter obliterado e reducionista, posto que o direito de recesso, como tantos outros institutos jurídicos, não pode ser adequadamente entendido se analisado exclusivamente sob o prisma das disposições legais que o consagram.

Daí a importância decisiva de nos determos, no item subseqüente, na análise não apenas do conceito do direito de recesso, mas também da função que o mesmo é chamado a desempenhar, a fim de que não se tirem ilações indevidas, a partir de conceituações prévias, que desviam o intérprete da exegese sistêmica do instituto em estudo.

Deveras, o direito de recesso ou de dissidência do acionista - pela nossa lei epigrafado como direito de retirada - é matéria que vem dando margem às mais calorosas discussões. Nem poderia ser de outra forma. Situa-se ela, talvez, no epicentro dos conflitos entre acionistas controladores, de um lado, e acionistas minoritários, de outro.

Já se disse, com propriedade, que o instituto do recesso reflete a tensão permanente entre os interesses individuais dos sócios e as necessidades de desenvolvimento da empresa; não se pode condenar o acionista a permanecer em uma empresa que não-atende mais aos seus interesses. A legislação visa proteger esse acionista e permitir que ele se desligue da "nova" companhia, pela qual ele não se sente mais atraído. ${ }^{8}$

A par das discussões essencialmente jurídico-doutrinárias sobre a natureza desse direito - em princípio a de um negócio jurídico que produz a extinção da relação jurídica entre o acionista e a companhia, caracterizando-se por ser manifestação unilateral de vontade ou reclamação, na voz sempre autorizada de Pontes de Miranda ${ }^{9}$ — e inserindo-se ele, a nosso ver impropriamente, no quadro dos direitos individuais dos acionistas, o caráter eminentemente ideológico desse

8. Cf. Alfredo Lamy Filho e José Luiz Bulhões Pedreira, "A Lei das S.A. , Rio de Janeiro, Renovar, 1966, v. II, p. 339.

9. Tratado de Direito Privado, Parte Especial, t. L, São Paulo, Editora Revista dos Tribunais, $1984, \S 5.328,2$, p. 342 . 
direito torna-se indisfarçável, bastando, para tanto, que se recorde as vicissitudes por que passaram aqueles direitos individuais dos acionistas (Sonderrecht), consagrados no BGB alemão do final da centúria passada, mas duramente castigados durante o período nazista, em que foi editada a Aktiengesetz, de 1937

Assim, é certo que o direito de recesso - como acontece, sobretudo, com o direito de voto - acompanha, de certo modo, a evolução democrática das sociedades anônimas e sua posterior involução atual para um caráter predominantemente aristocrático, como nos demonstra a doutrina mais autorizada a respeito da matéria.

Modesto Carvalhosa, ${ }^{10}$ por exemplo, em epígrafe a que denominou "Involução política refletida na Lei $n$. 6.404, de 1976", assinala com a costumeira propriedade:

"Temos, assim, que as Leis n. 6.404, de 1976, e n. 9.457, de 1997, não-somente deixaram de evoluir com referência à lei de 1940, como involuíram profundamente no que respeita ao principal direito do acionista, qual seja, o de participar das deliberações sociais em assembléia geral.

A Lei n. 6.404, de 1976, não-pode ser alinhada na concepção democrática da sociedade anônima, fundada no contrato social, em que o voto é o principal instrumento de participação e de representação social"

Já Rachel Sztajn,, ${ }^{11}$ após assinalar as diferenças existentes em matéria de direito de recesso no plano do Direito Comparado, mesmo no que se refere às "legislações pertencentes a uma mesma família" assevera que "a suspeita de que o direito de recesso não constitui instituto voltado para a tutela de minoritários torna-se mais e mais intensa e impõe a busca de outra hipótese".

Apesar de aceitar a idéia de que as relações entre a maioria e a minoria acionárias são, efetivamente, a "pedra de toque de qualquer sistema de sociedades" conclui a referida professora que:

10. Comentários à Lei de Sociedades Anônimas, v. 2, Editora Saraiva, 1997, p. 283.

11. "O direito de recesso nas sociedades comerciais", in Revista de Direito Mercantil n. 71, JulhoSetembro/1988, pp. 50 a 54 , especialmente p. 51. 
"Ora, aceita essa afirmação, se o recesso for direito voltado para a tutela de minorias, deveria estar presente em todas as legislações, independentemente do sistema jurídico, pois a questão maioria/minoria não é própria apenas do Direito brasileiro".

Aurelio Menéndez Menéndez, ${ }^{12}$ depois de assinalar que a concepção democrática da sociedade anônima, enquanto forma de grande empresa, entrou em crise com a tendência de concentração e de unificação do poder, acelerando-se cada vez mais, dado que a necessidade de se assegurar a maior eficácia possível à gestão da empresa social fez com que o poder se deslocasse para os chamados órgãos da administração, tece as seguintes considerações:

"Si es ésta la realidad, es natural que nos preguntemos sobre el sentido que desde esta perspectiva puede tener la diferenciación entre accionistas de control y accionistas inversores de fondos, o si se quiere, para seguir recordando las ideas expuestas, sobre el sentido que tienen las acciones sin voto. Parece que por este lado la respuesta no es dudosa: las acciones sin voto significarían que en una buena parte lo que era la piedra de toque de la organización del poder queda suprimida. En otros términos, que frente a una sociedad anónima de base democrática, con el voto del socio como origen de todo poder y la soberanía de la junta como principio cardinal de su estructura, caminamos hacia una sociedad anónima que, volviendo en cierto modo — sólo en cierto modo - a lo que fue en sus orígenes, trata de suprimir el voto del accionista y de constituirse sobre una base más bien oligárquica, fundada en el dominio de los socios que aspiran a participar en la administración y en el poder de gestión concentrado en los órganos de dirección y las minorias de control. Pero desde este momento decae o desaparece el instrumento de defensa del accionista en forma particularmente aguda. Y el Derecho que, como la Naturaleza - según una feliz expresión - 'tiene horror al vació, buscará, sin duda, los mecanismos compensadores al poder liberado de los administradores y los equipos de dirección"

12. "Ensayo sobre la evolución actual de la Sociedad Anónima", Cuadernos Civitas, Ed. Revista de Occidente, Madrid, 1974, p. 38. 
De minha parte, não-posso deixar de me manifestar a respeito de tema tão-apaixonante, na feliz expressão de Paulo Salvador Frontini. ${ }^{13} \mathrm{O}$ direito de recesso sempre foi - e continua a sê-lo no presente - um convite permanente à reflexão. Não que me revolva o peito, é claro, a esperança íntima de dar alguma contribuição em matéria sobre a qual já se pronunciaram as mais autorizadas vozes no mundo do Direito.

Além do mais, opiniões isoladas não-alteram o curso natural das coisas, máxime quando expressas nos acanhados limites de uma simples palestra...

De toda sorte, estou pessoalmente convencido de que o conteúdo do direito de recesso não se confunde, efetivamente, com a essência dos chamados direitos individuais ou intangíveis do acionista, resultando daí, talvez, a melhor explicação para a sua assimetria entre as mais diversas legislações e mesmo para a sua completa inexistência em algumas outras.

E não se confunde pela simples e boa razão de que entre os direitos individuais dos acionistas estão albergados direitos de natureza absolutamente diversa.

Mostrou-o, com a precisão admirável de sempre, Fábio Konder Comparato, ${ }^{14}$ destacando tanto a existência de direitos materiais, ${ }^{15}$ com a finalidade voltada à obtenção de bens econômicos, quanto a de remédios jurídicos, ${ }^{16}$ estes consubstanciados nos meios ou recursos de realização ou de proteção daqueles direitos materiais.

Esclarece, igualmente, o preclaro professor, que alguns dos direitos individuais dos acionistas correspondem a prerrogativas essenciais do sócio, independentemente do tipo de sociedade mercantil, pois tais prerrogativas seriam inerentes a qualquer sociedade, podendo-se afirmar que, sem aquelas, não existiria esta última. Exemplifica o citado mestre "com o caso paradigmático do direito de

13. Revista de Direito Mercantil n. 86, pp. 71 e ss., especialmente p. 75.

14. "Valor de reembolso no recesso acionário", Revista dos Tribunais, v. 563, pp. 48 a 56.

15. Por exemplo, o direito de participação dos lucros sociais (inciso I) e o direito de participar do acervo da companhia, em caso de liquidação (inciso II), ambos do art. 109 da Lei n. 6.404.

16. Por exemplo, o direito de fiscalizar, na forma prevista na lei, a gestão dos negócios sociais (inciso III do art. 109). 
participar dos lucros sociais, com a correlata regra da nulidade das sociedades leoninas" estas previstas no art. 288 do Código Comercial. ${ }^{17}$

E nos completa Comparato: ${ }^{18}$

"Já o mesmo não ocorre quando o direito individual é reconhecido em lei unicamente para a proteção do interesse minoritário, a modo de contrapeso ao princípio do governo social pela maioria. Exatamente porque não se cuida, aí, de prerrogativa ligada à própria essência da sociedade, nem todas as legislações consagram tais direitos, ou os alçam à categoria de poderes intangíveis"

Daí porque afirmamos, linhas atrás, que a inserção do direito de recesso no âmbito dos chamados direitos individuais, essenciais, intangíveis ou fundamentais do acionista — a par de sua notória insuficiência teórica, posto situarlhe o gênero próximo sem, contudo, indicar-lhe a diferença específica — pode representar até mesmo um certo perigo, na medida em que parece retirar do direito de recesso a sua verdadeira natureza de um remédio jurídico.

E por se tratar de remédio, desejo antecipar, já nestas linhas introdutórias, a minha posição francamente favorável à existência desse direito de recesso, não-obstante os problemas que a sua utilização abusiva gera não apenas na vida empresarial brasileira como, igualmente, na de outros países. ${ }^{19}$

Mas já se disse, com felicidade, que a diferença entre o remédio e o veneno é a quantidade. Pois bem: o recesso bem dosado sempre foi e continuará sendo um remédio jurídico; se mal, infelizmente, degenera em abuso.

Como, porém, abusus non tollit usum, como diziam os latinos, não será pela ocorrência de distorções - e elas existiram realmente - que se vai condenar o instituto às trevas do banimento, como querem alguns. Não posso aceitar, por exemplo, a supressão pura e simples desse direito nas hipóteses de cisão, assim

17. Diz esse artigo do Código: "É nula a sociedade ou companhia em que se estipular que a totalidade dos lucros pertença a um só dos associados, ou em que algum seja excluído, e a que desonerar de toda a contribuição nas perdas as somas ou efeitos entrados por um ou mais sócios para o fundo social"

18. Idem, p. 50.

19. Tal fenômeno ocorreu, por exemplo, na Itália, conforme será mostrado mais adiante, no capítulo referente à legislação comparada. 
como também não-concordo com algumas das limitações que lhe foram impostas nas hipóteses de incorporação, de fusão e de participação em grupo de sociedades, tal como procedeu a Lei n. 9.457/97, embora também pense com Paulo Frontini, Rachel Sztajn e com tantos outros que, em princípio, deixa de existir fundamento para o exercício do direito de recesso, nas companhias abertas, quando o acionista tem ampla e irrestrita possibilidade de negociar livremente os seus papéis nas Bolsas de Valores.

Quero deixar registrado, aliás, que sempre fui - e continuo a sê-lo de forma cada vez mais pronunciada - uma espécie, meio fora de moda, de democrata por fatalidade congênita.

Se há um texto de que me orgulharia muito de subscrever - e oxalá a minha assinatura viesse aposta a algumas centenas de milhares de outras - é aquele muito recente de Norberto Bobbio, ${ }^{20}$ no qual, numa livre tradução, assim se expressou:

"Eu sou um democrata convicto, ao extremo de continuar a defender a democracia, ainda quando ela seja ineficiente, corrupta, e corra o risco de precipitar-se nos dois extremos da guerra de todos contra todos, ou da ordem imposta do alto. A democracia é o lugar onde os extremistas não prevalecem (e se prevalecem, a democracia está terminada). Essa é também a razão pela qual as alas extremas, em enfileiramento político pluralista, de esquerda ou de direita, acham-se unidas pelo ódio à democracia, ainda que por opostas razões"

Entendo que o direito de recesso - conquanto tenha sido muito utilizado no Brasil de forma divorciada de suas verdadeiras funções, a ponto de falar-se numa "indústria do recesso" — representa o mais importante mecanismo de contrapeso ao poder incontrastável do acionista controlador, sendo, de certo modo, o reverso da medalha, na qual um de seus lados estampa a garantia constitucional de cada um poder associar-se livremente.

Não foram poucas, porém, as críticas existentes sobre o direito de recesso - quase sempre, aliás, inteiramente procedentes —, tal como se achava previsto na redação original da Lei n. 6.404. Os próprios autores do anteprojeto, Alfredo Lamy Filho e José Luiz Bulhões Pedreira, ao fazerem um balanço dos dez 
anos de vigência da lei, asseveravam que o único instituto que mereceria reparos, na verdade, era o do direito de recesso, tendo em vista as disfunções ocorridas durante a década inicial de vigência daquele texto legal. ${ }^{21}$

Fábio Konder Comparato, após conferência pronunciada no Seminário sobre a Lei das S.A. e seus efeitos sobre as Sociedades de Economia Mista, na Secretaria da Fazenda do Estado de São Paulo, declarava a utilização do direito de recesso como negócio, já que muitas empresas tinham as suas ações cotadas em Bolsa por valor muito abaixo do valor patrimonial, tornando extremamente vantajoso, em tais hipóteses, o exercício do direito de retirada, ${ }^{22}$

Arnoldo Wald, igualmente, assim se pronunciou sobre o direito de recesso:,23

"Reminiscência da ultrapassada concepção contratualista da sociedade, constitui o direito de recesso um aspecto da resilição unilateral ou denúncia, entendida como forma de rescisão parcial do contrato de sociedade justificada pela modificação das cláusulas essenciais, que levaram o acionista a subscrever ou adquirir as suas ações"

Pouco mais adiante, prossegue esse ilustre professor:

"É um remédio excepcional de proteção aos não controladores contra o ato voluntário da maioria que pode ser considerado abusivo pelo fato de alterar

21. Cf. Jornal A Gazeta Mercantil, edição de 28 de novembro de 1986, em entrevista realizada por Cecília Costa, p. 27, na qual esses autores afirmaram a necessidade de pouquíssimas reparações, estando entre elas a alteração do critério do valor do reembolso, nas hipóteses de recesso, trocando-se o do valor patrimonial das ações por uma média de cotação do título na Bolsa de Valores.

22. Cf. a entrevista concedida pelo citado professor ao Jornal A Gazeta Mercantíl, edição de 13 de março de 1977, Caderno das Finanças, tendo como título "O direito de recesso como negócio"

23. Cf. Revista de Direito Mercantil n. 40, pp. 29 a 35, especialmente pp. 30-31. Já na mesma $R D M$, de n. 62, no artigo "Dez anos de yigência da Lei das Sociedades Anônimas", pp. 5 e ss., especialmente p. 9 , esse mesmo professor limitou-se a fazer o seguínte comentárío sobre o direito de retirada: "No tocante ao recesso, o art. 45 dá lei determina que o reembolso se faça de acordo com o valor de patrimônio líquido contábil. Ocorre que, muitas vezes, o patrimônio líquido contábil não corresponde ao valor real da sociedade, seja pelo fato de nele não constarem bens intangíveis, seja em virtude da depreciação de determinados móveis ou imóveis. Discute-se então se o patrimônio líquido, que deve servir de base ao reembolso deve ser o contábil ou o real. Tanto a letra da lei, como o seu espírito, nos levam a atender ao valor de balanço (atualizado quando decorridos mais de 60 dias). Há, todavia, uma tendência doutrinária em sentido inverso" 
as regras básicas que ensejaram a criação da empresa. A idéia de abuso e até de opressão da maioria, à qual se refere o direito inglês, faz parte das condições necessárias para o exercício de recesso, que não se justifica diante da evolução normal da atividade societária, que se modifica em virtude das condições externas, de ato do príncipe ou até de fatores tecnológicos" (grifos do autor).

Não-obstante todas essas judiciosas considerações — inteiramente procedentes, segundo a minha maneira de ver — não nos filiamos entre aqueles que preferiam ver banido da legislação brasileira o direito de recesso.

Corrigir os excessos e as distorções havidas com o propósito de pôr termo aos que se transformaram em profissionais da retromencionada "indústria do recesso" é ponto inquestionável. Mas esse objetivo deve estar inteiramente voltado a extirpar a especulação antiética, isto é, a coibir o procedimento caviloso de adquirir ações com o propósito exclusivo de dissentir das deliberações da assembléia geral, ensejadoras de tal direito, e receber o reembolso das ações correspondentes.

Apesar das críticas inevitáveis que devem ser feitas no que se refere às inovações promovidas pela Lei n. 9.457/97 — e nós as exteriorizaremos, sem hesitação, no decorrer do presente trabalho - não se poderá deixar de reconhecer que ela atingiu em cheio os abusos cometidos pelos profissionais do ramo, conforme iremos analisar no capítulo pertinente.

Feitas essas considerações a título meramente introdutório, passemos ao exame do conceito e das funções do instituto ora estudado.

II. Conceito e função do direito de recesso.

\section{a. Conceito.}

Modesto Carvalhosa ${ }^{24}$ define o direito de recesso como "a faculdade legal do acionista de retirar-se da companhia, mediante a reposição do valor patrimonial das ações respectivas", acrescentando ainda:

"Trata-se de um negócio jurídico, em virtude do qual a companhia é obrigada a pagar aos acionistas dissidentes o valor de suas ações. Constitui uma 
resilição unilateral ou denúncia. É, portanto, reminiscência da concepção contratualista da sociedade anônima, que ainda subsiste em diversas esferas da sua estrutura"

Praticamente idêntico é o ensinamento de Nelson Eizirik, ${ }^{25}$ segundo o qual o direito de recesso "constitui uma faculdade legal do acionista de retirar-se da sociedade, em determinadas circunstâncias, recebendo dela o valor real $e$ atualizado das suas ações" prosseguindo que ele "consiste, pois, no poder jurídico de extinguir, por ato unilateral, nos casos previstos em lei, as relações que vinculam o sócio à companhia, passando à posição de credor da mesma, pelo valor de reembolso de suas ações"

Conclui esse ilustre autor que se trata o direito de recesso, portanto, "do direito que o acionista tem de, ao discordar de certas deliberações da Assembléia Geral, nos casos previstos em lei, retirar-se da Sociedade mediante o reembolso do valor de suas ações"

Fábio Konder Comparato, ${ }^{26}$ como deflui naturalmente das considerações já transcritas na parte introdutória desta exposição, considera que o direito de recesso é "um remédio jurídico e não um direito material à obtenção de lucros ou vantagens. É remédio reconhecido em lei para a proteção de interesses individuais do acionista, não correspondentes, portanto, ao interesse social. Deste, o intérprete primeiro continua sendo o majoritário ou controlador. Ele tem o direito - e, em certas circunstâncias, até mesmo o dever — de tomar a iniciativa das deliberações sociais que contrariam o interesse dos minoritários. Mas o sacrifício destes é considerado iníquo sem uma compensação: o poder atribuido aos dissidentes de se retirarem da sociedade com o reembolso do valor de sua participação social"

Rachel Sztajn, no artigo retrocitado, assevera que "o recesso é meio de o acionista deixar a sociedade, não de fazer lucros às suas custas"

Não são necessárias maiores considerações a respeito dessa noção sobre a qual não paira dúvida. Estamos diante de um direito que tem o acionista discordante de deliberações da assembléia geral, sobre matérias taxativamente previstas em lei, de retirar-se da companhia mediante o reembolso do valor de suas

25. Reforma das S.A. \& do Mercado de Capitais, Renovar, p. 61.

26. Artigo citado, p. 50. 
ações. Resta saber - e isso é o que tentaremos responder ao longo da presente exposição - em que limites e em que extensão deve ele ser exercido a fim de que a sua função básica não seja desvirtuada.

Assinale-se, igualmente, que a doutrina costuma designar o recesso, com apoio em Giampiccolo, ${ }^{27}$ como uma declaração unilateral de vontade do acionista dissidente de natureza receptícia, ${ }^{28}$ havendo dificuldades, no entanto, no seu enquadramento em apenas uma das modalidades de participação, como demonstrou, com razão, Tavares Guerreiro. ${ }^{29}$

b. Função.

A função do direito de recesso, portanto, a partir das lições já transcritas, parece ser bastante evidente: garante-se ao acionista minoritário, nas hipóteses legalmente previstas, o direito de se retirar da sociedade, em contrapartida à derrota de sua vontade na votação da assembléia geral.

Questão das mais relevantes a ser necessariamente enfrentada diz respeito à necessidade ou-não de que o exercício do direito de recesso esteja condicionado à existência de prejuízo sofrido pelos acionistas dissidentes.

Assinale-se, de início, que a redação original do art. 137, caput, e do seu $\S 1^{\circ}$ da Lei n. 6.404, era a seguinte:

"Art. 137. A aprovação das matérias previstas nos incisos I, II e IV a VIII do art. 136 desta Lei dá ao acionista dissidente direito de retirar-se da companhia, mediante reembolso do valor das suas ações (art. 45), se o reclamar à companhia no prazo de 30 (trinta) dias, contados da publicação da Ata da Assembléia Geral.

27. "La Dechiarazione Recettizia", Milão, Giuffrè, 1959, pp. 44-50.

28. Cf. José Alexandre Tavares Guerreiro, "Direito de Retirada e Poder de Retratação", in Revista de Direito Mercantil n. 44, pp. 22-27; V., também, Rachel Sztajn, art. cit., p. 51.

29. Mostrou o professor Guerreiro, no citado artigo, que a manifestação do recesso tanto contém uma participação de notícia quanto uma participação de exigência — verdadeira intimazione, na expressão de Giorgio Giampiccolo. Afigura-se complexa tal categorização, com efeito, porquanto poderia vislumbrar-se, igualmente, uma participação de intenção do acionista, posto que a possível retratação posterior dos controladores descaracterizaria, em parte, a participação de exigência para a participação de mera intenção. Relembre-se, a propósito, que a classificação clássica das declarações receptícias é pentapartida: propostas, participações de notícia, participações de exigência, participações de previsão e participações de intenção. 
$\S 1^{\circ} \mathrm{O}$ acionista dissidente de deliberação da assembléia, inclusive $o$ titular de ações preferenciais sem direito de voto, pode pedir o reembolso das ações de que, comprovadamente, era titular na data da assembléia, ainda que se tenha abstido de votar contra a deliberação ou não tenha comparecido à reunião".

Com o advento da Lei n. 7.958, de 20 de dezembro de 1989, a redação do caput do artigo passou a ser a seguinte:

"A aprovação das matérias previstas nos incisos I, II, IV, V e VII do art. 136 desta Lei dá ao acionista dissidente direito de retirar-se da companhia, mediante reembolso do valor de suas ações (art. 45), se o reclamar à companhia no prazo de 30 (trinta) dias, contados da publicação da Ata da Assembléia Geral"

A redação atual do artigo e do inciso I acha-se expressa nos seguintes termos:

"A aprovação das matérias previstas nos incisos I a VI do art. 136 dá ao acionista dissidente direito de retirar-se da companhia, mediante reembolso do valor das suas ações (art. 45), observadas as seguintes normas:

I - nos casos dos incisos I e II do art. 136, somente terá direito de retirada o titular de ações de espécie ou classe prejudicadas;"

Entendiam alguns, mesmo antes dessa última redação que faz alusão expressa ao titular de ações de espécie ou classe prejudicadas, que a existência de prejuízo era indispensável.

Wilson de Souza Campos Batalha, ${ }^{30}$ por exemplo, afirmava:

"Não-basta ser dissidente. É de mister provar legítimo interesse e o prejuizo resultante da deliberação assemblear. Não pode o preceito, norteado pelos propósitos mais elevados de proteger as minorias contra as arbitrariedades da maioria, constituir-se em fonte de abusos e locupletamentos.

30. "Comentários à Lei das Sociedades Anônimas", Rio de Janeiro, Forense, 1977, v. 2, (arts. 106 a 188), pp. 645-646. 
Assim, é indispensável, a justificar o direito de retirada, que a modificação do objeto social seja substancial ou fundamental, não bastando qualquer ligeira modificação, acréscimo ou redução, desde que o núcleo fundamental dos interesses persista integro"

Outros entendem que, com a atual redação do inciso I, impõe-se a necessidade de existência de prejuízo.

Leslie Amendolara, em recentíssimo livro, ${ }^{31}$ é categórico a respeito:

"O inciso I do art. 137 dispõe que somente terá direito de retirada o titular de ações de espécie ou classe prejudicadas. $O$ texto anterior era omisso e o atual visou deixar claro que, para ocorrer a dissidência, terá que haver prejuízo. $O$ silêncio da lei anterior poderia propiciar a alguém, mesmo não tendo sido prejudicado pela mudança, pleitear o recesso e obter vantagem indevida, recebendo o valor de suas ações por preço superior ao de mercado, na sociedade aberta" (grifos do próprio autor).

Nelson Eizirik, ${ }^{32}$ por sua vez, assim se expressa:

"Nos termos do art. 137, I, em sua nova redação, a aprovação das matérias previstas nos incisos I e II do art. 136, acima mencionadas, somente dá o direito de retirada ao titular de ações de espécie ou classe prejudicadas.

A reforma adota o princípio de que, na hipótese acima, somente cabe o exercício do direito de recesso se o acionista dissidente demonstrar a ocorrência de prejuízos, conforme já manifestado pela jurisprudência dos tribunais.

Os prejuizos não se presumem, cabendo ao dissidente a sua comprovação, exceto no caso de redução de dividendo obrigatório".

Seja-me permitido, nesse particular, discrepar de tão judiciosas considerações. Mesmo irrestritamente afinado com o pensamento de todos os que

31. "Os Direitos dos Acionistas Minoritários" São Paulo, Editora STS Publicações e Serviços Ltda., setembro de 1998, pp. 71 e 72.

32. Ob. cit., pp. 77-78. 
condenam a utilização do direito de recesso como instrumento para abusos - o que me leva a concordar tanto com a afirmação de Fábio Konder Comparato de que o direito de recesso estava sendo utilizado por muitos como "negócio" quanto de Rachel Sztajn no sentido de que "o recesso é meio de o acionista deixar a sociedade, não de fazer lucros às suas custas" e mesmo com Wilson de Souza Campos Batalha de que o preceito não pode se constituir em fonte de abusos e locupletamentos —, não-posso aceitar como correta a dicção do inciso I do art. 137 da Lei n. 6.404, que atribui o direito de retirada ao "titular de ações de espécie ou classe prejudicadas."

E não-posso fazê-lo pela simples e boa-razão de que a deliberação da assembléia capaz de ensejar o exercício do direito de recesso não se insere no âmbito dos atos ilícitos.

Já em 1982, Fábio Konder Comparato, ${ }^{33}$ no luminoso artigo tantas vezes citado, chamara atenção para o fato de que o ato praticado pelo acionista controlador ensejador do direito de recesso não se enquadraria no âmbito dos atos ilícitos, significando apenas a compensação de interesses particulares sacrificados legitimamente em favor do interesse social.

Nelson Eizirik, ${ }^{34}$ igualmente, é enfático em afirmar que:

"O ato praticado pela companhia contrariamente aos interesses dos minoritários e que enseja o direito de recesso não constitui ato ilícito" (grifo do autor).

Modesto Carvalhosa, com toda a razão, alude corretamente à necessidade de um interesse protegido. Diz-nos, com efeito, esse autor:

"A redação do inciso I do presente art. 137 fala em 'espécie ou classe prejudicadas'. O legislador, ao assim dispor, procurou refletir a tendência jurisprudencial e doutrinária, no sentido de que o exercício do recesso pressupõe a possível diminuição de direitos patrimoniais dos minoritários. Não-obstante, o legislador despreparado fala em 'prejuízo', desconhecendo que o termo é sinônimo

33. "Valor de reembolso no recesso acionário", Revista dos Tribunais, v. 563, p. 50.

34. Ob. cit. p. 61 . 
de dano, decorrente de ato ilícito que afeta o patrimônio material ou moral de alguém.

Ocorre que as alterações institucionais ou estatutárias da companhia constituem atos lícitos e previstos expressamente em lei, não violando em si direito algum do acionista, pelo que não se pode falar em dano. Assim, é inadmissível falar-se em prejuízo do acionista alcançado pela alteração estatutária ou estrutural da companhia. $O$ direito do minoritário nasce quando o seu interesse patrimonial é alcançado pelas alterações havidas" (grifos do autor).

E conclui o Eminente professor com inteiro acerto:

"A regra de que o direito cabe a qualquer acionista não deve, no entanto, ser entendida como absoluta. Há o pressuposto de que o interesse do acionista foi atingido" (grifos do autor).

III. O direito de recesso na legislação comparada.

O título do presente capítulo leva em conta, evidentemente, as célebres advertências de Ascarelli ${ }^{35}$ aos critérios metodológicos no estudo do Direito Comparado. Breves referências feitas de forma assistemática e exclusivamente baseadas em comentários de autores, sem nenhum contato direto com a realidade do país mencionado, não podem significar, propriamente falando, Direito Comparado. Assim, com esta necessária ressalva, passemos ao exame da legislação comparada.

Comecemos pelo que dispunha o Código de Comércio italiano, de 1882, ao que saibamos o pioneiro no trato da matéria em todo o mundo. ${ }^{36}$ Ali se

35. Diz-nos o autor citado, in "Problemas das Sociedades Anônimas e Direito Comparado", São Paulo, Saraiva, 1969, p. 5: "São, mais ou menos, as que sempre foram feitas pelos que se dedicam ao direito comparado. Bastaria, nesse sentido, relembrar o velho livro de Amari, que, em substância, faz a advertência em que se resume quanto vai dito nestas páginas: o que cumpre estudar é o direito comparado e não simplesmente a legislação comparada, a menos que se queira correr o risco de tirar conclusões que, pelo fato de não serem completas, poderiam ser, afinal, erradas"

36. Cf., a propósito, Tullio Ascarelli, ob. cit. p. 80, nota de rodapé n. 38. Ver, igualmente, Egberto Lacerda Teixeira, "Das Sociedades por Quotas de Responsabilidade Limitada", Max Limonad, 1956, $\S 101$, p. 218; Pontes de Miranda, ob. cit., t. L, p. 340; Leães, ob. cit., p. 224 e Modesto Carvalhosa, ob. cit., p. 739. 
dispunha, no art. $158,{ }^{37}$ que seria possível o recesso do acionista de deliberação de assembléia em várias hipóteses.

Vivante o considerava um freio e um remédio contra o poder ilimitado das assembléias de modificar o próprio estatuto, acrescentando que se tratava de um instituto de ordem pública que não podia ser tolhido aos acionistas, nem pelo estatuto, nem pela assembléia. ${ }^{38}$

Não-obstante a grande controvérsia instalada durante o período de vigência desse art. 158 - seja no tocante à natureza pública ou privada do direito de recesso; seja, igualmente, acerca das vantagens e desvantagens de sua manutenção; seja, ainda, no que se referia à licitude das restrições estatutárias à eficácia e ao exercício desse direito - , parecia entender-se, predominantemente, que se tratava de direito inderrogável por deliberação da maioria, ${ }^{39}$ mas derrogável pelo estatuto originário, segundo autorizada doutrina. ${ }^{40}$

37. Dizia esse artigo: "Qualora l'atto costitutivo o lo statuto nos disponga altrimenti, è sempre necessaria la presenza di tanti socii che rappresentono i tre quarti del capitale sociale, ed il voto favorevole di tanti socii intervvenutti che rappresentono almeno la metà del capital medesimo, per deliberare: $1^{\circ}$ ) lo schioglimento antecipato della società; $2^{\circ}$ ) la prorogazione della sua durata; $3^{\circ}$ ) la fuzione com altra società; $4^{\circ}$ ) la riduzione del capitale sociale; la reitegrazione o l'aumento del capitale stesso $6^{\circ}$ ) il cambiamento dell'oggeto della società; ogni altra modificazione dell atto costitutivo.

La maggioranza stessa è inoltre richiesta in tutti i casi specialmente designati dalla legge.

I socii dissenzienti dalle deliberazioni indicate nei ns. $3^{\circ}, 5^{\circ}$ e $6^{\circ}$ e dalla prorogazione della durata della società, se non è acconsentita nell'atto costitutivo, hanno diritto di ricedere della società ed di ottenere il rimborso delle loro quote ed azioni in proporzione dell'ativo sociale secondo l'ultimo bilancio approvato.

Il recesso dev'essere dichiarato dagli intervenuti all'assemblea entro venticuattro ore dalla chiusa di essa, e dagli altri socii entro un mese dalla publicazione della deliberazione nel giornale degli annunzi giudiziarii, sotto pena di decadenza"

38. "Trattato di Diritto Commerciale", v. II, Le Società Comerciali, Francesco Vallardi, 1935, § 517: "Il diritto di recesso agisce come un freno e un rimedio contro il potere illimitato delle assemblee di modificare il proprio statuto. $\grave{E}$ un istituito d'ordine pubblico, che non può essere tolto agli azionisti nè dallo statuto nè dall'assemblea"

39. Cf. Tullio Ascarelli, idem, ibidem, além da citação que se fará, logo mais adiante, no texto principal. Cesare Vivante, "Trattato di Diritto Commerciale", Milão, Ed. Francesco Vallardi, 1935, v. II, p. 249, § 517 e nota de rodapé n. 66; Vighi, "I diritti individuali degli acionisti" p. 97 e Soprano, "Della responsabilità civile e penale degli amministratori di società per azioni", I, p. 385.

40. Cf. Tullio Ascarelli, idem, ibidem. Em sentido contrário, Vivante, ob. cit., v. II, p. 250. 


\section{Diz-nos a respeito Tullio Ascarelli: ${ }^{41}$}

"A jurisprudência italiana (interpretando o art. 158 do Cód. de Comércio de 1882) admitiu, às vezes, não poder, a maioria, derrogar o direito de retirada, mas poder, o acionista, previamente renunciar a ele. Admitiu-se, conseqüentemente, que o direito de retirada não pode ser excluído por meio de uma modificação do estatuto, mas que o pode na própria constituição da sociedade, o que se dava, na Itália, com muita freqüência. Admitiu-se até, na jurisprudência italiana, que o direito de retirada está implicitamente excluído quanto às modificações estatutárias previstas pelo estatuto. A despeito da divergência de Vivante (v. II, n. 517) foi essa a opinião, talvez, dominante (Scialoja A., Saggi di Vario Diritto, v. II, p. 405; Ap. de Milão, de 22 de janeiro de 1926 e Ap. de Turim, de 27 de janeiro de 1926, Foro It., 1926, I, p. 801)".

A par de tais considerações no que concernia à inderrogabilidade do direito de retirada por deliberação da maioria e à possibilidade ou não de o acionista renunciar previamente a ele, por disposição estatutária em tal sentido, cabia esse direito, em princípio, da decisão que aprovasse a fusão de uma sociedade com outra ou a incorporação de uma por outra.

Enquanto na fusão era esse direito outorgado aos acionistas das diferentes sociedades envolvidas nesse processo de concentração empresarial, na incorporação o recesso só se admitia aos acionistas da sociedade incorporada.

Em segundo lugar, admitia-se a retirada na reintegração ou aumento de capital com contribuição adicional dos sócios. Embora a doutrina distinguisse as duas situações - na primeira, com a redução inicial do capital social, posteriormente recomposto com a nova versão de recursos pelos acionistas; e, na segunda, com o novo aporte de capital por parte dos acionistas - , era o direito de recesso permitido em ambas as situações.

Em terceiro lugar, concedia-se o direito de retirada na prorrogação do prazo de duração da sociedade, concebendo-se, no caso, que tal tipo de decisão significava, em última análise, dilatar a responsabilidade do acionista para além do prazo inicialmente pactuado. 
E, finalmente, em quarto e derradeiro lugar, afigurava-se possível o direito de retirada nos casos de alteração do objeto social, com fundamento de que ninguém poderia ser obrigado a contribuir com recursos para uma atividade diversa da qual havia sido motivado o seu investimento.

No período entre 1882 e 1942 - data em que entraria em vigor o famoso Código Civil daquele país - a tendência no Direito italiano foi no sentido da progressiva exclusão do direito de recesso em determinadas hipóteses, ${ }^{42}$ já se revelando, desde então, a utilização da supressão desse direito como instrumento de políticas macroeconômicas.

Essa tendência foi confirmada pelo atual art. 2.437 do Código Civil italiano, de 1942, acerca do Diritto di recesso, que assim dispôs a respeito da matéria:

"I soci dissenzienti dalle deliberazioni riguardanti il cambiamento dell'oggeto o del tipi della società, o il trasferimento della sede sociale all'estero (2369) hanno diritto di ricedere dalla società e di ottenere il rimborso delle proprie azioni, secondo il prezzo medio dell'ultimo semestre, se queste sono quotate in borsa, $o$, in caso contrario, in proporzione del patrimonio sociale risultante dal bilancio dell' ultimo esercizio (2423).

La dichiarazione di recesso deve essere comunicata com raccomandata dai soci intervenuti all'assemblea non oltre tre giorni dalla chiusura di questa, e dai soci non intervenuti non oltre quindici giorni dalla data dell'iscrizione della deliberazione nel registro delle imprese (2188; att.100).

È nullo ogni patto che esclude il diritto di recesso o ne rende più gravoso l'esercizio".

Percebe-se, portanto, que o direito de recesso foi bastante modificado no Código de 1942, relativamente ao art. 158 do anterior Código de Comércio, de

42. A Lei n. 431, de 1915, excluiu o recesso nas hipóteses de fusão e nos aumentos de capital em que este se fizesse exclusivamente com a emissão de ações preferenciais. Já o R.D.L., de 1932, suprimiu esse direito, mesmo nas hipóteses de concentração em que ocorresse a alteração do objeto social. Relata Giuseppe Donadio (Il recesso del socio, Milão, Giuffrè, 1940, pp. 37 e ss.), igualmente, que em 1923 o legislador italiano ampliou a regra anterior de que o recesso não seria cabível nos aumentos de capital feitos com subscrição de ações preferenciais, passando a considerar o mesmo também incabível nos aumentos de capital com emissão de ações ordinárias. Cf. Tullio Ascarelli, ob. cit., pp. 392-393 e Fré, Rivista di Diritto Commerciale, 1933, v. I, pp. 632 e 762. 
1882. Está prevista no Direito peninsular a possibilidade de recesso apenas para os sócios dissidentes das deliberações da assembléia geral que versarem sobre a mudança do objeto social da companhia, da transformação do tipo societário e, ainda, da transferência da sede social para o Exterior.

Conclui-se que o legislador italiano, na esteira das críticas que a doutrina lançava a respeito da largueza do direito de recesso, tal como fora previsto no antigo Código de Comércio, visou coibir a atitude egoística de alguns sócios minoritários que desejavam prontamente exercer o seu direito de receber o reembolso de suas participações.

Brunetti, em seu famoso tratado, ${ }^{43}$ depois de criticar a péssima utilização do direito de recesso na Itália, com possível prejuízo econômico da sociedade, acentuou que:

"Il recesso è oggidì ridotto a proporzioni assai modeste concedendosi limitatamente a quelle deliberazioni che riguardano: a) il cambiamento dell'oggetto o del tipo della società; b) il trasferimento della sede sociale all'estero.

Negli altri casi: di variazione del capitale sociale (riduzione, reintegrazione, aumento) e di fusione com altra società, non è ammesso. E nei detti casi dovranno osservarsi le modalità previste dall'art. 2.437, che sono inderogabili anche per deliberazione dell'assemblea"

Mas, como bem observado por Egberto Lacerda Teixeira: ${ }^{44}$

"Se, por um lado, o Código Civil limitou, consideravelmente, o campo de aplicação do recesso, trouxe, por outro, o reconhecimento formal da natureza pública desse direito, ao fulminar, com a pena de nulidade, todo e qualquer pacto tendente a excluir ou a tornar mais oneroso o seu exercicio"

Em França, inexiste o direito de recesso. ${ }^{45}$ Se é certo, porém, que o art. 217 da Lei de Sociedades, de 1966, nada disponha a respeito, também é verdade que

43. "Trattato de Diritto delle Società": v. 2, Milão, Giuffrè, 1948, n. 677, pp. 422-423.

44. Ob. cit., pp. 219-220.

45. Cf. Carvalhosa, ob. cit., v. 2, p. 740; Rachel Sztajn, art. cit., p. 51. 
autorizada doutrina propugna pela sua adoção como forma de proteção das minorias contra o abuso das maiorias.

Veja-se, a propósito, o seguinte trecho de Dominique Schmidt: ${ }^{46}$

"Dans ces conditions, faute de pouvoir directement punir les responsables de l'abus, on se souciera davantage de protéger les victimes.L'insertion dans les statuts d'un droit de retraite (l) répond pleinement à cet objectif.

Certes, cette institution a été décriée (2), à juste titre, parce qu'elle aboutissait à affaiblir la société au moment précis où elle avait besoin de toutes ses ressources (3). Mais ces critiques perdent toute autorité dès lors que l'exercice du droit ne répond plus à des mobliles égoïstes, mais correspond à un procédé de défense de la minorité contre les abus de majorité. Le droit de retraite pourrait ainsi être limité au seul cas où une décision de justice aurait constaté l'abus, et il s'exercerait, par exemple, dans les deux mois de la décision. D'un côté les dirigeants seraient mal venus à se plaindre de la retraite des minoritaires et d'une diminution des forces de la société, alors qu'ils en seraient les responsables; de l'autre côté, l'exercice du droit permettrait à la minorité de libérer ses intérêts de la loi des majoritaires: ses actions trouveront acquéreur (4) et il suffira de veiller à ce que le prix offert corresponde réellement à leur valeur dans la société".

E, rematando tais comentários, diz Dominique Schmidt ${ }^{47}$ que o legislador, de 1966, como vimos, não-previu o exercício do direito de recesso em caso de abuso de poder da maioria; antes, pelo contrário, as disposições do art. 217 da Lei de 24 de julho de 1966 proibiram de regulamentá-lo estatutariamente, lamentando esse autor que, no estado atual do Direito, a minoria não possa esperar obter outras sanções para o abuso da maioria que o estrito reestabelecimento da igualdade entre os acionistas; a desinteligência entre os acionistas imputável aos majoritários torna-se, em contrapartida, impunível, o que não garante o futuro.

$\mathrm{Na}$ Alemanha, a situação não difere muito ${ }^{48}$ das que se acaba de expor. Não-obstante a norma constante do art. 375 , que admite a possibilidade do recesso

46. "Les droits de la minorité dans la Société Anonyme", bibliothèque de Droit Commercial, dirigida por R. Houin, t. 21, Sirey, n. 255, pp. 192-193.

47. Ob. cit., pp. 193-194.

48. Cf. Carvalhosa, idem, ibidem; Rachel Sztajn, idem, ibidem. 
na hipótese de transformação da forma da sociedade, com a compra pela companhia da parcela de capital do acionista, entende-se haver caráter indenitário nessa compra e não, propriamente, o exercício de um direito de recesso.

Além disso, é certo que o art. 57 da Akztiengesetz exclui a possibilidade do exercício do direito de recesso, tendo em conta a proibição expressa de que sejam devolvidas as contribuições dos sócios ao capital social.

Nos EUA, as diversas legislações estaduais discrepam sobre a amplitude desse direito. ${ }^{49}$ Mas, como esclarece Leães, ${ }^{50}$ assemelham-se na previsão das três hipóteses tópicas: a. nas fusões e incorporações; b. na venda de parcelas substanciais do ativo da companhia e c. em determinadas alterações estatutárias.

Acrescenta esse autor:

"Na grande maioria das legislações estaduais, limita-se o recesso às hipóteses de fusão e incorporação. É o caso da Lei de Delaware, que, como se sabe, disciplina a vida de mais de noventa por cento das companhias de mercado nos Estados Unidos ( $\$ 262$. Payment for stock or membership of person objecting to merger or consolidation). Cerca de metade das legislações estaduais acrescentam a esta hipótese a de recesso no caso de cessão ou permuta de todo ou parte do ativo da companhia, operada fora do curso regular dos negócios. É o caso das Lei de Nova Iorque, \$ 910. Em menor número, inscrevem-se as leis estaduais que acolhem o direito de recesso na hipótese de charter amendment, como é exemplo a Lei de Ohio (\$ 1701.74). A Texas Business Corporation Act estende ainda o recesso às hipóteses de prorrogação (extension) ou novação (revival) do contrato social. Em contraposição, a Lei do West Virginia não contempla a hipótese de recesso na disciplina do anonimato. Consolidando essa prática multifária o Model Business Corporation Act, em seu $\S 80$, disciplina os casos em que assiste ao acionista $o$ direito de recesso, ou seja, nas fusões e incorporações e na venda ou troca de todo ou parte substancial do ativo da companhia".

Em Portugal, ${ }^{51}$ a Lei de 1901 , no $§ 3^{\circ}$ de seu art. 41, inspirando-se no art. 158 do Código de Comércio da Itália, retromencionado, reconheceu aos sócios

49. Cf. Carvalhosa, ob. cit., v. 2, pp. 739-740; Rachel Sztajn, idem, ibidem.

50. Ob. cit., \$230, p. 225.

51. Cf. Azevedo Souto, "Lei das Sociedades por Quotas Anotada", 3a ed., Coimbra, 1941, p. 135. 
que não concordassem com a prorrogação, fusão, aumento, reintegração ou redução do capital social, desde que o declarassem na assembléia geral respectiva, o direito de retirar-se da sociedade, recebendo o reembolso da quantia correspondente ao seu capital na proporção do último balanço aprovado.

Essa disciplina jurídica do direito de recesso vinha complementada pela disposições constantes dos $\S \S 5^{\circ}$ e $6^{\circ}$ desse mesmo art. 41 , in verbis:

"O direito de reembolso não tira ao sócio, que tenha declarado a intenção de se apartar da sociedade, no caso em que se torne efetiva a deliberação da assembléia, o direito de se opor, judicialmente e nos termos gerais, a qualquer forma de redução do capital"

"Os sócios que se apartarem da sociedade não ficam exonerados das prestações correspondentes às quotas respectivas, na parte em que essas prestações forem necessárias para pagamento das obrigações contraídas até a data do registro definitivo da modificação social".

Na Argentina, o direito de recesso ocorre na hipótese de dissolução antecipada, transformação, incorporação, fusão ou cisão.

$\mathrm{Na}$ lei uruguaia, onde o direito de recesso acha-se previsto, semelhantemente ao que ocorre em nossa lei, entre os direitos intangíveis do acionista, no art. 319 da Lei acionária, prevê-se o exercício de tal direito no art. 363, nos casos de fusão, cisão, transformação, dissolução antecipada, transferência de domicílio para o Exterior e no caso de mudança substancial do capital social.

Fica assim - apenas palidamente entrevisto - o direito de recesso em algumas legislações alienígenas.

IV. O direito de recesso na sociedade por cotas de responsabilidade limitada.

O Decreto-Lei n. 3.708, de 10 de janeiro de 1919, que disciplina até hoje a sociedade por cotas de responsabilidade limitada no Brasil, previu a matéria em seu art. 15, do teor seguinte:

"Assiste aos sócios que divergirem da alteração do contrato social a faculdade de se retirarem da sociedade, obtendo o reembolso da quantia 
correspondente ao seu capital, na proporção do último balanço aprovado. Ficam, porém, obrigados às prestações correspondentes às quotas respectivas, na parte em que essas prestações forem necessárias para pagamento das obrigações contraídas, até a data do registro definitivo da modificação do estatuto social"

Como é sabido, a nossa mais Alta Corte de Justiça editou a respeito da matéria a Súmula 265 , in verbis:

"Na apuração de haveres não prevalece o balanço não aprovado pelo sócio falecido, excluído ou que se retirou"

Não-parece indispensável, para a coerência interna da presente exposição, que se adentre o mérito do direito de recesso nas sociedades por cotas de responsabilidade limitada. E isto pela razão de que, como acentuado por Rachel Sztajn, o direito de retirada desponta como algo muito mais relacionado às sociedades de capitais do que com as sociedades de pessoas, circunstância que parece prevalecer na maioria dos casos das sociedades limitadas.

De toda sorte, imprescindível a referência ao meritório estudo de Vera Helena de Mello Franco ${ }^{52}$ no que respeita ao direito de recesso no âmbito das sociedades por cotas, principalmente no que toca à oportuna insistência com que essa autora sublinha, no estudo citado, a distinção entre dissolução parcial e recesso acionário.

V. O direito de recesso na Lei n. 6.404/76.

Não-posso deixar de assinalar, em sede liminar — não-obstante as nossas observações anteriores no sentido de que as sociedades anônimas parecem marchar, tanto no Brasil quanto no Exterior, progressivamente, para um sistema cada vez mais oligárquico, em detrimento da democracia acionária -, que a Lei $\mathrm{n}$. 6.404/76, fruto de um anteprojeto elaborado por juristas de nomeada como Alfredo Lamy Filho e José Luiz Bulhões Pedreira, e com vigor conduzido pelo então ministro Mário Henrique Simonsen, de saudosa memória, representou inquestionável

52. "Dissolução parcial e recesso nas sociedades por quotas de responsabilidade limitada. Legitimidade e Procedimento. Critério e Momento de Apuração de Haveres" in Revista de Direito Mercantil n. 75, pp. 19 a 30. 
avanço no Direito Comercial brasileiro e, em especial, em nossa legislação societária, que se regia, à época, pelo Decreto-Lei n. 2.627, inferior tecnicamente ao diploma de 1976.

O item n. 10 da Exposição de Motivos, inicialmente preparada pela Comissão de Juristas autora do anteprojeto e enviada ao senhor ministro da Fazenda, já tivera a ocasião de ressaltar que o texto procurara "construir — com normas que se distribuem praticamente por todos os seus capítulos — sistema de proteção dos acionistas minoritários sem sacrificar, todavia, a ação livre, ainda que responsável, da maioria e dos administradores, indispensável ao funcionamento e à própria viabilidade da empresa"

O professor Alfredo Lamy Filho destacou, com propriedade, que o então anteprojeto se constituía num "tratado de paz entre maioria e minoria $e$ encontrar o ponto ótimo desse equilíbrio é o principal desafio" concluindo, em síntese feliz, que:

"A maioria precisa de liberdade para bem administrar a sociedade e a minoria precisa de garantias para nela investir e permanecer"

A Lei n. 6.404/76 disciplinou a matéria no art. 137 da seguinte forma, em sua redação original:

"Art. 137. A aprovação das matérias previstas nos incisos I, II e IV a VIII do art. 136 desta Lei dá ao acionista dissidente direito de retirar-se da companhia, mediante reembolso do valor das suas ações (art. 45), se o reclamar à companhia no prazo de 30 (trinta) dias, contados da publicação da Ata da Assembléia Geral.

$\S 1^{\circ} \mathrm{O}$ acionista dissidente de deliberação da assembléia, inclusive o titular de ações preferenciais sem direito de voto, pode pedir o reembolso das ações de que, comprovadamente, era titular na data da assembléia, ainda que se tenha abstido de votar contra a deliberação ou não tenha comparecido à reunião.

$\S 2^{\circ} \dot{E}$ facultado aos órgãos da administração convocar, nos 10 (dez) dias subseqüentes ao término do prazo de que trata este artigo, a assembléia geral para reconsiderar ou ratificar a deliberação, se entenderem que o pagamento do preço do reembolso das ações aos acionistas dissidentes, que exerceram o direito de retirada, porá em risco a estabilidade financeira da empresa. 
$\S 3^{\circ}$ Decairá do direito de retirada o acionista que o não exercer no prazo fixado".

VI. O direito de recesso na Lei n. 7.958, de 20 de dezembro de 1989 — a malfadada "Lei Lobão".

Essa lei - desastradamente, diga-se desde logo — suprimiu os incisos VI e VIII do art. 137 - que cuidavam, respectivamente, do direito de retirada nas hipóteses de incorporação da companhia em outra, sua fusão ou cisão e na participação em grupo de sociedade — na remissão feita por este art. 137 ao art. 136 da mesma lei.

"Art. 137. A aprovação das matérias previstas nos incisos I, II, IV, Ve VII do art. 136 desta Lei dá ao acionista dissidente direito de retirar-se da companhia, mediante reembolso do valor das suas ações (art. 45), se o reclamar à companhia no prazo de 30 (trinta) dias, contados da publicação da Ata da Assembléia Geral"

Tratou-se, como se sabe, de mais um dos casuísmos vergonhosos que grassam em nossa ordenação jurídica, pois a aprovação da lei, feita à socapa, envolvia os interesses de uma única companhia de grande porte desejosa de ver incorporada uma controlada sua sem que fosse eventualmente molestada pelo recesso dos minoritários.

Modesto Carvalhosa foi absolutamente enfático a respeito desse melancólico episódio: ${ }^{53}$

"A Lei n. 7.958, de 1989, de caráter grotescamente casuístico porque fruto da demanda de uma única companhia de grande porte que desejava incorporar controlada, sem o questionamento eventual do recesso dos minoritários - não logrou o seu intento supressivo de vários direitos de retirada, garantidos como essenciais. Esse triste episódio legislativo recebeu a repulsa unânime da opinião pública e dos meios jurídicos, pois constituiu verdadeiro estelionato legislativo. Ocorre que, pela ausência de técnica, tornou-se o 'diploma' totalmente ineficaz. Por esse execrável monumento do casuísmo legislativo, pretendia-se 
suprimir o direito de retirada nos casos de fusão, cisão e incorporação. Para tanto, 'alterava' o caput do art. 137 da lei societária, para dele 'excluir' aquelas operações de reorganização societária".

O jornal "O Estado de S. Paulo" à p. 3 de sua edição de 12/01/90, comentou a lei como "escandaloso casuismo legislativo"

A revista "Visão", naquela época, fez reportagem contendo vários pronunciamentos contrários ao texto legal, sob o título: "Lei das S/As. Golpe infeliz contra acionistas" (edição de 24/01/90).

Tanto a Bolsa de Valores de São Paulo quanto a Comissão de Valores Mobiliários - que possuem, presumivelmente, a mais larga experiência com o problema - manifestaram-se francamente contrárias à medida.

A "Gazeta Mercantil" de 16/01/90, registrou, na oportunidade, o seguinte pronunciamento do vice-presidente da Bovespa: "O mercado não foi ouvido. Em tempos de democracia essa questão deveria ser levada à audiência pública"

E o fez, também, o então presidente da CVM, Martin Wimmer, que disse ter aquela entidade sido consultada em setembro do ano anterior, por carta, tendo se manifestado contra a aprovação do Projeto.

O próprio consultor-geral da República - que tem competência específica para assistir o presidente da República em matéria de anteprojetos e projetos a ele submetidos - afirmou que "o direito dos acionistas minoritários deve ser preservado" e que o presidente da República teria sido "mal-assessorado" na análise do Projeto.

E o então presidente da República — senador José Sarney reconheceu expressamente: "Sancionei a lei em boa-fé, mas vejo agora que foi um erro" conforme noticiava "O Estado de S. Paulo", em 13/01/90.

As reações no meio jurídico, como não poderia deixar de ser, foram as piores possíveis. Mesmo assim, como só acontece em nosso país, houve quem se prestasse a fazer a defesa da lei.

Para o então ministro da Justiça, Saulo Ramos, a medida era boa para restringir a ação de "litigantes contumazes" Segundo ele, "não podemos dar ao acionista minoritário pretextos para infernizar a vida das companhias. Muitos acionistas minoritários e aproveitadores já prejudicaram, com suas exigências, 
negociações envolvendo fusões ou incorporações de empresas". "Precisamos afastar os famosos chatos..." (Gazeta Mercantil de 16/01/90).

O senador Edison Lobão, autor do Projeto que se converteu na lei em tela, apresentou a seguinte explicação, absolutamente incompreensível mesmo para os espíritos afeitos à matéria: "O sentido da lei é o de defender os acionistas minoritários. Procuramos garantir o seu direito de influir nas decisões das sociedades anônimas, não fechar as portas para os descontentes"

Tentou explicar, depois ("Folha de S. Paulo", 24/01/90), que só queria alterar o direito de recesso na hipótese do art. 265 , vale dizer, no caso de constituição de grupos de sociedades.

Mas na justificativa apresentada (Projeto de Lei do Senado n. 182, de 1989, por esse senador subscrito) está dito: "Duas hipóteses, dentre as enunciadas pelo art. 136 (sic) da Lei n. 6.404/76 mostraram-se, na prática destes últimos dez anos, contrárias ao livre desenvolvimento de empresas constituídas pela modalidade de ações (sic). Trata-se de incorporação, fusão, cisão, e participação em grupos de sociedades. Tais providências, quando decididas pelos sócios, são salutares e benéficas para o desenvolvimento dos negócios sociais, não justificando, sobretudo na incorporação ou fusão, a retirada do dissidente através do desgastante processo da apuração do patrimônio líquido, muitas vezes usado abusivamente para, através da criação de embaraços, obterem-se vantagens indevidas." (cf. Diário Oficial do Congresso Nacional, Seção II, de 29.06.89, pp. 3.202/3.203).

Houve, ainda, outros defensores dessa malfadada lei. Exemplo: Luíza Prisco Paraíso, professora de Direito Comercial da Fundação Getúlio Vargas e Faculdade Cândido Mendes, que não admite que "a posição dos minoritários venha a emperrar decisões de majoritários"

Ninguém mais duvida, ao que parece, do enorme equívoco da Lei n. 7.958. Ela eliminou a remissão feita no art. 137 da Lei n. 6.404 aos incisos VI e VIII. É evidente que a intenção do legislador ficou clara: ele quis abolir duas hipóteses de direito de recesso por parte de acionistas minoritários:

a. incorporação da companhia em outra, sua fusão ou cisão (inciso VI);

b. participação em grupo de sociedade (inciso VIII).

Sucede que, conforme anotado por Mauro Rodrigues Penteado, comercialista da Faculdade de Direito da Universidade de São Paulo — que realizou, em nossa opinião, a mais percuciente análise dessa matéria na doutrina 
brasileira - continuou a existir esse mesmo direito potestativo de recesso em mais cinco mandamentos na Lei n. 6.404 não-alterados pela famigerada Lei Lobão. Eram eles: art. 225, inciso IV; $\S \S 3^{\circ}$ e $4^{\circ}$ do art. 264; art. 230 (no caso das fusões, incorporações e cisões) e art. 270 (para os grupos societários).

A lei teria revogado, portanto, o direito de retirada nas hipóteses mencionadas apenas no artigo genérico da lei que cuida desse direito. Deixou de fazê-lo, porém, nos outros pontos da mesma Lei n. 6.404, onde esse direito vinha previsto e regulado.

Filiamo-nos — em todos os pronunciamentos realizados em aulas, palestras e conferências — à tese do ilustre professor Mauro Rodrigues Penteado. E o fizemos, fundamentalmente, por julgar ser de somenos importância, na aplicação das leis, a intenção do legislador.

Como disse com muita propriedade o professor Eros Roberto Grau, numa de suas inolvidáveis palestras, ${ }^{54}$ se fosse importante perquirirmos a intenção do legislador na interpretação dos textos legais seria necessário contarmos com duas espécies de assessoramento, ambos fora do meio jurídico. Precisaríamos contar com o auxílio de um psicólogo e, eventualmente, de um militante kardexista ${ }^{55} \ldots$

O fato é que a Lei Lobão terminou por gerar enorme dificuldade para a apresentação de conclusões seguras acerca da subsistência ou-não do direito de retirada nas hipóteses de fusão, incorporação, cisão e participação em grupo de sociedades, no Direito brasileiro.

\section{a. Posição da Doutrina.}

Muito já se escreveu, até o momento, sobre o problema. São diversos os pronunciamentos a respeito. Não-obstante, é possível afirmar-se que a doutrina se acha claramente dividida. Escusava esclarecer, evidentemente, que a discussão

54. Trata-se da palestra proferida no III Congresso Internacional de Direito do Consumidor, realizado em Canela-RS, em março de 1992, e publicada na Revista Direito do Consumidor n. 05, pp. 183 e ss.

55. No texto referido na nota de rodapé anterior, por evidente lapso de degravação e de revisão, constou, literalmente, que "seria necessária a colaboração de dois tipos de profissionais nãojurídicos: um psicólogo, para discernir a vontade do legislador, e, em outras hipóteses, algum exercício de catecismo haveria de ser praticado, dada a impossibilidade de se descobrir essa vontade" Claro está, portanto, que a expressão catecismo terá sido desastradamente introduzida no texto... 
apenas subsiste no que se refere ao período anterior à Lei n. $9.457 / 97$, posto que este texto revogou expressamente a Lei Lobão por referência expressa de seu art. $6^{\circ}$.

Favoráveis à subsistência do direito de recesso nas hipóteses de que se cuida estão, exemplificativamente, os professores Mauro Rodrigues Penteado, retromencionado (cf. Revista de Direito Mercantil n. 77, pp. 29 e ss.); Rubens Aprobato Machado (Revista de Direito Mercantil n. 82, pp. 46 e ss.); Paulo Salvador Frontini (Revista de Direito Mercantil n. 86, pp. 71 e ss.); Modesto Carvalhosa (Revista de Direito Mercantil n. 96, pp.21 e ss); Norma Jonssen Parente (Revista de Direito Mercantil n. 97. pp.67 e ss.); Maria Lúcia de Araújo Cintra (Revista de Direito Mercantil n. 98, pp. 80 e ss.) e Renata Brandão Moritz (Revista de Direito Mercantil n. 101, pp. 56 e ss.).

Em posição oposta, vamos encontrar o professor Jorge Lobo (Revista dos Tribunais n. 664, pp. 43 e ss.) num estudo que foi submetido e aprovado pelo Instituto dos Advogados Brasileiros do Rio de Janeiro; Alfredo Lamy Filho e José Luiz Bulhões Pedreira ("A Lei das S.A." Rio de Janeiro, Renovar, 1996, v. II, pp. 344 e 352 e Waldírio Bulgarelli ("Fusões, Incorporações e Cisões de Sociedades" São Paulo, Atlas, 1996, p. 237); José Edwaldo Tavares Borba ("Direito Societário" $2^{a}$ ed., Biblioteca Jurídica Freitas Bastos, 1995, pp. 332 e ss.).

\section{b. Posição da Jurisprudência.}

Somente logramos encontrar, até o momento, dois precedentes jurisprudenciais a respeito. Comentemos, em rápidas linhas, o primeiro deles.

Trata-se o primeiro de Acórdão da $2^{\mathrm{a}}$ Câmara Civil do Tribunal de Alçada de Minas Gerais, nos autos de Apelação Cível n. 116.737-1, julgada em 21 de agosto de 1991, na qual foi integralmente acolhida a tese defendida pelo professor Mauro Rodrigues Penteado.

Embora, no caso concreto, o direito fora manifestado antes da vigência da Lei n. 7.958 - o que, só por si, terá facilitado a decisão do Aresto, tendo em conta o direito adquirido e o ato jurídico perfeito - não resta dúvida de que o julgado em referência acolheu integralmente a argumentação desenvolvida pelo comercialista de São Paulo.

Recorde-se o seguinte trecho do voto do eminente relator, juiz José Brandão: 
"Ocorre que a Lei $n$. 7.958/89 modificou a redação do art. 137, da Lei n. 6.404/76, mas, com palavras de Mauro Rodrigues Penteado (in RDM, jan. março/90, p. 46) não modificou o direito de retirada contido na Lei $n$. 6.404/76.

Diz o comercialista (op. cit.): 'No afã de suprimirem o direito de recesso nas hipóteses em tela, os participantes do processo legislativo de elaboração da Lei n. 7.958 - o autor do Projeto 182/89, os assessores e parlamentares das comissões permanentes do Senado e da Câmara, o Ministério da Justiça - incorreram, data vênia, em gritante erronia. Eliminaram apenas a remissão feita no art. 137, VI e VIII da Lei n. 6.404, não se dando ao trabalho de compulsar o texto completo desse diploma legal, onde encontrariam esse mesmo direito potestativo dos acionistas previsto e assegurado em mais cinco outros mandamentos, que não foram feridos pela lei recém editada: os arts. 225, I, 264, $\S \S 3^{\circ}$ e $4^{\circ}$ e 230 (para as incorporações, fusões e cisões) e o art. 270, parágrafo único (para a constituição de grupos societários)'"

Após a citação desse longo trecho do estudo do professor Mauro Penteado, aduz o eminente relator:

"Comungo com a opinião do autor citado, de que o art. 137 da Lei n. 6.404 enuncia em caráter não exaustivo e não exclusivo as hipóteses de retirada, por remissão ao art. 136, que versa sobre matérias que exigem quorum qualificado para deliberação em assembléia-geral extraordinária".

O professor Paulo Salvador Frontini, ${ }^{56}$ em preciso comentário a respeito desse Aresto, teve a ocasião de destacar:

"Sobre a origem, tramitação, sanção e repercussão do diploma, é ocioso dispender energia em novos comentários. O tema foi esgotado em percuciente análise de talentoso comercialista ('A Lei n. 7.958/89 e a pretensa modificação do direito de retirada dos acionistas: uma discussão inócua' — Mauro Rodrigues Penteado, RDM 77/29)" 
Não apenas concordamos irrestritamente com o trecho retrotranscrito do professor Paulo Frontini quanto com esta sua outra conclusão que, a seguir, se transcreve:

"Pensamos que a $r$. decisão, ora comentada, deu solução razoável à espécie. Mas, com a devida vênia, longe está de colocar as grandes questões que o tema encerra, e muito menos de enfrentá-las.

Em instâncias superiores, por certo, a matéria será debatida com outra profundidade"

O segundo precedente jurisprudencial foi a Apelação Cível n. 187.636-4, também do Tribunal de Alçada de Minas Gerais, objeto do comentário retromencionado, de autoria de Maria Lúcia de Araújo Cintra, ${ }^{57}$ que assim se expressou:

"Embora dando uma desnecessária ênfase à interpretação autêntica da lei, ou seja, na suposta intenção do legislador, o Acórdão está bem fundamentado, com apoio na opinião de diversos juristas, na manifestação da CVM e ainda na interpretação sistemática da Lei $n$. 6.404/76.

A decisão não poderia ser diferente.

Com efeito, a interpretação sistemática da lei leva inevitavelmente à conclusão de que a Lei $n .7 .958$ não derrogou o direito de recesso na hipótese de incorporação.

$\mathrm{Na}$ realidade, as hipóteses legalmente admitidas para o exercício do direito de recesso não estão restritas àquelas enumeradas no art. 137. Outros artigos prevêem diferentes situações em que o acionista dissidente poderá retirar-se da companhia, como os arts. 22I(transformação), 236 (aquisição de controle por pessoas de direito público) e 256 (aquisição de controle por preço acima de valor determinado" 
E conclui a eminente advogada de São Paulo:

"Fica evidente, portanto, que o direito de retirada não está limitado às hipóteses elencadas no art. 137, desde que outro artigo disponha especialmente sobre a matéria como ocorre no caso em questão, diante do disposto no art. 230 da Lei . 6.404/76"

c. Posição da Instância Administrativa. Julgamento da Comissão de Valores Mobiliários.

Cabe registrar, por derradeiro, que a Comissão de Valores Mobiliários examinou o pedido de reembolso de acionistas da Panex S.A., que foram dissidentes da deliberação da assembléia que determinara uma cisão parcial.

Cuidou-se de uma assembléia geral extraordinária, realizada em 31 de dezembro de 1989, logo em seguida à entrada em vigor da Lei n. 7.958, com a empresa informando à CVM que não haveria direito de retirada tendo em vista esse novo texto legal.

Mas o relator da matéria, professor Ary Osvaldo Mattos Filho, então presidente daquela autarquia, optou por reconhecer o direito de retirada daqueles acionistas dissidentes, a despeito de os fatos terem ocorrido após a publicação da Lei Lobão.

Renata Brandão Moritz, em seu já citado estudo, ${ }^{58}$ dá notícia de que o Colegiado da Comissão de Valores Mobiliários também defendeu o direito dos acionistas minoritários dissidentes da incorporação da Sulina Alimentos S.A. pela Perdigão Agroindustrial S.A.

Diferente é o posicionamento atual daquela autarquia federal. Acompanhando a tendência de conceber a lei das sociedades anônimas como instrumento da política macroeconômica do Governo Federal, conforme tantas vezes salientado por Carvalhosa, passou ela, mesmo antes do advento da Lei n. 9.457/97, a entender que o recesso significaria um entrave ao livre desenvolvimento das empresas.

58. "As hipóteses de recesso na lei das sociedades anônimas", $R D M$ n. 101, p. 70, nota de rodapé n. 21 . 
Sabe-se que, no ano de 1996, em recurso interposto contra decisão proferida pela Superintendência de Empresas da Comissão de Valores Mobiliários a respeito do prazo para o exercício do direito de retirada, o Colegiado daquela autarquia deu provimento ao mesmo.

Ao fazê-lo, na verdade, revogou o entendimento anteriormente esposado - supedâneo daquelas decisões anteriores que não admitiam estivesse o direito dos acionistas minoritários coarctados pela Lei Lobão —, asseverando que a Lei n. 7.958/89, além de ter suprimido o inciso VI do rol do art. 137, houvera também revogado os arts. 225 , inciso IV e 230 da Lei n. 6.404/76.

Fundou-se o voto do relator, na oportunidade, na autorizada doutrina de Carlos Maximiliano, segundo a qual "extinta uma disposição ou um instituto jurídico, cessam todas as determinações que aparecem como simples conseqüências, explicações, limitações; ou se destinam a lhe facilitar a execução ou funcionamento, a fortalecer ou abrandar os seus efeitos", sendo certo, assim, que "o preceito principal arrasta em sua queda o seu dependente ou acessório"

Desde tal julgamento pelo Colegiado, passou a CVM a entender não mais existente o direito de recesso nas hipóteses de fusão, cisão e incorporação.

Assinale-se, em remate ao capítulo, que essa malfadada Lei Lobão já pertence ao passado. Foi ela expressamente revogada pelo art. $6^{\circ}$ da Lei n. 9.457. a seguir examinada, no que pertine ao nosso tema do recesso acionário.

VII. O direito de recesso na Lei n. 9.457/97.

Dispõe o art. 137 da Lei n. 6.404, na redação atual que lhe deu a Lei n. 9.457/97:

"Art. 137. A aprovação das matérias previstas nos incisos I a VI do art. 136 dá ao acionista dissidente direito de retirar-se da companhia, mediante reembolso do valor das suas ações (art. 45), observadas as seguintes normas:

I nos casos dos incisos I e II do art. 136, somente terá direito de retirada o titular de ações de espécie ou classe prejudicadas;

II nos casos dos incisos $I V$ e $V$, somente terá direito de retirada o titular de ações:

a. que não integrem indices gerais representativos de carteira de ações admitidos à negociação em bolsas de futuros; $e$ 
b. de companhias abertas das quais se encontram em circulação no mercado menos da metade do total das ações por ela emitidas, entendendo-se por ações em circulação no mercado todas as ações da companhia menos as de propriedade do acionista controlador;

III o reembolso da ação deve ser reclamado à companhia no prazo de trinta dias contados da publicação da ata da assembléia geral;

IV o prazo para o dissidente de deliberação de assembléia especial (art. 136, $\S 1^{\circ}$ ) será contado da publicação da respectiva ata;

$V$ o pagamento do reembolso somente poderá ser exigido após a observância do disposto no $\$ 3^{\circ}$ e, se for o caso, da ratificação pela assembléia geral;

$\S 1^{\circ} \mathrm{O}$ acionista dissidente de deliberação da assembléia, inclusive o titular de ações preferenciais sem direito de voto, poderá exercer o direito de reembolso das ações que, comprovadamente, era titular na data da primeira publicação do edital de convocação da assembléia, ou na data da comunicação do fato relevante objeto da deliberação, se anterior.

$\S 2^{\circ} \mathrm{O}$ direito de reembolso poderá ser exercido no prazo previsto no inciso III do caput deste artigo, ainda que o titular das ações tenha-se abstido de votar contra a deliberação ou não tenha comparecido à reunião.

$\S 3^{\circ}$ Nos dez dias subsequientes ao término do prazo de que trata o inciso III do caput deste artigo, contado da publicação da ata da assembléia geral ou da assembléia especial que ratificar a deliberação, é facultado aos órgãos da administração, se entenderem que o pagamento do preço do reembolso das ações aos acionistas dissidentes que exerceram o direito de retirada porá em risco a estabilidade financeira da empresa.

$\S 4^{\circ}$ Decairá do direito de retirada o acionista que não o exercer no prazo fixado"

Não se questiona, na verdade, quanto aos propósitos da Lei $\mathrm{n}$. 9.457/97 no sentido de acabar com a retroaludida "indústria do recesso"

Mas em que sentido poder-se-ia dizer que a nova lei, efetivamente, visou coibir apenas aquele procedimento eticamente condenável de se adquirir ações de uma determinada companhia com o objetivo exclusivo de dissentir das deliberações sociais para poder exigir o valor do reembolso pertinente?

Não-tenho dúvida em afirmar que, ao dispor o $\S 1^{\circ}$ do art. 137 que o acionista dissidente de deliberação da assembléia poderá exercer o direito de reembolso das ações de que, comprovadamente, era titular na data da primeira 
publicação do edital de convocação da assembléia, ou na data da comunicação do fato relevante objetọ da deliberação (se anterior à publicação do edital), fícou impedida a prática dos profissionais do recesso que, cientes de que a companhia estava prestes a tomar decisões ensejadoras do direito de retirada, adquiriam rapidamente as suas ações antes que se realizasse a assembléia geral...

Ninguém, creio eu — exceção feita aos inescrupulosos minoritários de plantão, que não se envergonhavam em fazer a mais deslavada chantagem com controladores de grandes empresas - , poderá criticar a nova lei nesse particular.

No que se refere à supressão do direito de recesso, porém, nas hipóteses de cisão ${ }^{59}$ de companhia aberta, e nas limitações a ele impostas nos casos de incorporação e fusão da mesma modalidade societária, razão parece assistir, mais uma vez, a Modesto Carvalhosa.

Salientou o ilustre professor, de forma candente, em várias passagens de sua obra, seu inconformismo com o novo texto legal, desde o seu nascedouro, quando era ainda o Projeto de Lei n. 1.564, de 1996. Sobre ele, assim se expressou Carvalhosa: ${ }^{60}$

"Inscreve-se portanto esse projeto no processo de contínuo solapamento dos direitos essenciais dos acionistas, a duras penas incluídos na Lei n. 6.404, de 1976, por força das emendas aprovadas pelo Congresso Nacional, em 1976. Confirma o 'Projeto Kandir' o caráter crescentemente oligárquico do 'capitalismo' nacional, que leva à impossibilidade cada vez mais evidente de criação de um mercado de ações no País".

A manobra governamental ficou, com efeito, absolutamente evidente. Era sabido que o modelo de privatização do País calcava-se, entre outros aspectos, na prévia cisão de empresas estatais, concessionárias de serviços públicos, principalmente nos setores de telefonia e de geração e distribuição de energia elétrica.

59. A leitura combinada dos $\S \S 3^{\circ}$ e $4^{\circ}$ do art. 223 , em sua nova redação, leva à conclusão de que o direito de recesso só permanece aos minoritários na hipótese de as companhias sucessoras no processo de cisão não remanescerem na condição de sociedades abertas.

60. Ob. cit., v. 2, p. 732. 
Para diminuir o custo dessas privatizações, o Projeto de Lei n. 1.564, de 1996, transformado na Lei n. 9.457/97 — embora atenuado pela Emenda Hauly, ${ }^{61}$ que outorgou certas compensações patrimoniais aos acionistas minoritários investiu duramente contra os interesses desses últimos.

Era escusado dizer que a retórica oficial, quase sempre mergulhada na hipocrisia que tem servido de supedâneo ao Poder Público no Brasil, não iria reconhecer o óbvio, isto é, que o novo texto legal, como muito bem destacado por Carvalhosa, a exemplo do que já ocorrera anteriormente com a Lei Lobão, "inscrevese no processo de contínuo solapamento dos direitos essenciais dos acionistas, a duras penas incluidos na Lei $n$. 6.404"

De um lado, deu-se o poderoso ataque com a supressão do direito de recesso na hipótese de cisão e com a sua progressiva neutralização nos casos de fusão e de incorporação.

De outro lado, com truculência que nos pareceu ainda maior, o texto legal aboliu a obrigatoriedade da oferta pública aos acionistas minoritários nos casos de transferência de controle, revogando-se integralmente o art. 254 e parcialmente o art. 255 da Lei n. 6.404, disposições que representavam a síntese de longas discussões no Congresso Nacional por ocasião da aprovação de seu texto.

Reconheço, como não poderia deixar de ser, o caráter altamente polêmico desse ideal de igualdade entre todos os acionistas nas cessões de controle acionário. Bastaria lembrar, a esse propósito, a mais clássica de todas as obras nessa matéria, na qual o professor Fábio Konder Comparato, ${ }^{62}$ depois de acurada reflexão, mostrava que o poder de controle, como realidade econômica, não poderia deixar de ser considerado como tendo um valor próprio, distinto das ações singularmente consideradas. Ao referir-se ao famoso e substancioso estudo de Ballantine, ${ }^{63}$ observou o ilustre professor:

"Um autor norte-americano afirmou o óbvio, ao declarar que 'de modo geral, o poder de controlar a eleição de diretores e, portanto, de gerir $e$

61. Nome do deputado Luiz Carlos Hauly, relator do Projeto Kandir.

62. "O Poder de Controle na Sociedade Anônima", São Paulo, Editora Revista dos Tribunais, 1975 , tese com a qual conquistou o cargo de professor titular da Faculdade de Direito da Universidade de São Paulo.

63. Henry Winthrop Ballantine - Ballantine on Corporations, ed. Revista, Chicago (Callagnhan and Company), 1946, p. 433. 
controlar os bens, negócios e o comércio de uma grande companhia, de decidir sobre as diretrizes de sua política empresarial e o dispêndio de grandes somas de dinheiro, de indiretamente nomear e fixar a remuneração de seus prepostos e representantes, é um bem valioso ou poder de grande valor, mesmo se a companhia se encontra apenas em situação de pagar salários e não-dividendos. '"

Prossegue esse mesmo professor ${ }^{64}$ ponderando que, se o nosso sistema econômico fundamenta a apropriação do lucro empresarial, com base no exclusivismo da responsabilidade daqueles que efetivamente assumem as responsabilidades pelo poder, como "democratizar" o poder de controle? Não seria o caso, então, de se partilhar o preço da alienação não apenas entre todos os acionistas, mas também entre todos os componentes do complexo empresarial, abarcando, igualmente, os empregados?

Outro argumento praticamente irrespondível, utilizado por Comparato, diz respeito às garantias prestadas pelo titular do controle acionário, por ocasião de sua alienação. Seja mediante a prestação de caução das próprias ações em garantia de empréstimos concedidos à sociedade alienada, seja pela outorga de avais em títulos de crédito, como se falar aqui em igualdade de situação jurídica entre controladores alienantes e os demais acionistas não controladores?

Mas, já naquela oportunidade, o mesmo professor Comparato sugeria ao legislador brasileiro duas medidas prudentes, sendo que a primeira delas seria exatamente a de atribuir aos acionistas não-controladores, titulares de ações há mais de dois anos, o direito de recesso pelo seu valor contábil, apurado segundo os algarismos do último balanço social aprovado, em razão de uma transferência de controle acionário, onerosa ou gratuita. ${ }^{65}$

Como se sabe, grande foi a discussão por ocasião da tramitação do Projeto pelo Parlamento Nacional. Os arts. 254 e 255 da Lei n. $6.404 / 76$ não constavam do Projeto original e foram introduzidos em virtude de emenda apresentada no Senado pelo senador Otto Cirilo Lehman, prevendo a obrigatoriedade de oferta pública, quando da alienação do controle de companhia aberta, mediante a qual seria preservado ao acionista minoritário o direito de receber o mesmo preço pago pelos adquirentes ao acionista controlador.

64. Ob. cit., p. 249.

65. Ob. cit., p. 251. 
Esse tratamento igualitário passou a ser desejado, a partir de 1972, logo após a despudorada cessão de controle de um banco comercial em que os controladores adquiriram a preço irrisório as ações dos minoritários, revendendo-as, em seguida, por preço muitas vezes superior ao dessa aquisição, motivando o deputado Herbert Levy a apresentar, na Câmara dos Deputados, o Projeto de Lei n. 1.042, segundo o qual "na transferência de controle acionário, por venda, os acionistas minoritários nas sociedades anônimas de capital aberto receberão por suas ações preço igual ao estabelecido para as ações do grupo ou grupos majoritários"

O mesmo deputado, na legislatura seguinte, iria oferecer um substitutivo, nele propondo que os titulares de ações preferenciais da companhia recebessem $25 \%$ do ágio pago aos acionistas majoritários, desde que tal ágio correspondesse ao dobro ou mais do valor de mercado das ações.

Mas, como foi dito linhas atrás, por ocasião da discussão do Projeto que iria se converter na Lei n. 6.404, prevaleceu a solução proposta pela Emenda Lehman, que recebeu aquiescência da maior parte da doutrina. A Lei n. 9.457/97 promoveu profunda alteração nessè estado de coisas.

O deputado Luiz Carlos Hauly destacou, em seu voto, o seguinte:

"Tanto o oportuno projeto de lei como as sugestões oferecidas, assim como o PL n. 622, de 1995, foram cuidadosamente apreciados, tendo em vista o fortalecimento do mercado de capitais de risco, a conciliação dos interesses envolvidos nas sociedades por ações e a busca do ponto de equilíbrio desejável nas relações entre a maioria e a minoria, visando, assim, melhorar o sistema adotado, que se baseia na efetiva responsabilidade do controlador da empresa e de seus administradores, na precisa definição dos direitos do minoritário e na ampla publicidade, para que o que é imperioso, também, ensejar à Comissão de Valores Mobiliários melhores condições para bem exercer a fiscalização que lhe cabe, na defesa da empresa, do minoritário, do crédito público e das instituições que atuam no mercado".

Não-obstante seja forçoso reconhecer que a Emenda Hauly - como haveria de ficar conhecido o substitutivo ao Projeto de Lei n. 622-A — amenizou ligeiramente a situação dos acionistas minoritários, dando-lhes algumas vantagens de caráter patrimonial, não resta dúvida de que ela referendou as principais inovações 
trazidas pelo Projeto original do Governo, claramente tendentes a obedecer aos propósitos da nova política macroeconômica deste último.

Carvalhosa ${ }^{66}$ é incisivo a respeito:

"E no plano das iniquiidades a Lei n. 9.457, de 1997, acolheu a supressão dos arts. 254 e 255 da Lei n. 6.404, de 1976, que tratavam da oferta pública em caso de alienação de controle. Tal retrocesso demonstra mais uma vez a persistência e aprofundamento do perfil institucional da lei societária, sempre a serviço das macropolíticas governamentais do momento. No caso presente, sua política está voltada a atender a implantação de um Estado neoliberal. Some-se a esse tatcherismo tropical a tendência sempre demonstrada pelos controladores $e$ suas entidades de classe, contrários ao procedimento de eqüidade representado pela oferta pública. Continua vigendo no Brasil a célebre declaração do Barão de Fürstenberg feita numa assembléia do Deutsche Bank, realizada nos fins do século passado: 'Os acionistas são uns tolos e uns arrogantes; tolos porque nos dão o seu dinheiro e arrogantes porque querem receber dividendos' Acrescente-se que essa supressão de um direito fundamental dos acionistas recebeu inclusive o apoio explícito da Comissão de Valores Mobiliários, embora seja encarregada por lei de promover a defesa dos investidores no mercado de ações"

Não nos pareceu feliz, com efeito, a forma pela qual a Lei n. 9.457/97 introduziu essas alterações em nossa lei societária. E nossa crítica - em brevíssimas linhas, ${ }^{67}$ como não poderia deixar de ser — pode ser sintetizada nas seguintes considerações: ${ }^{68}$

A supressão da obrigatoriedade da oferta pública aos acionistas minoritários, nos casos de transferência de controle, revogando-se integralmente o art. 254 e parcialmente o art. 255 da Lei n. 6.404 - disposições que, como dissemos, não-obstante a polêmica sobre o tema, representavam a síntese de longas discussões no Congresso Nacional por ocasião da aprovação de seu texto - sem a

66. Ob. cit., v. 2, p. 286.

67. Tais críticas cingem-se, apenas, tendo em conta o âmbito da presente exposição, às questões relacionadas ao direito de recesso.

68. Estamos nos atendo, por questões de tempo e de espaço, aos três pontos que consideramos mais delicados na reforma promovida pela Lei n. 9.457/97. 
correspondente outorga do direito de recesso pareceu-nos, efetivamente, um doloroso retrocesso à proteção das minorias acionárias no Direito brasileiro.

Em segundo lugar, não-vislumbramos nenhuma razão para a abolição integral do direito de recesso na hipótese de cisão, salvo, como já foi dito, para atender a uma política macroeconômica momentânea do Governo Federal relacionada à diminuição dos custos da privatização das companhias estatais.

Mas a cisão de uma companhia constitui uma das alterações mais sensíveis no interesse do acionista minoritário, sendo, por isso mesmo, o direito de recesso preservado em tal hipótese nos países em que o adotam, como tivemos a oportunidade de verificar.

Em terceiro - e por derradeiro - julgamos que os critérios utilizados pelo legislador para autorizar o recesso se afiguram ambíguos, em alguns casos, levando a crer que, na prática, eles poderão conduzir à progressiva neutralização desse direito.

Refiro-me aos casos de fusão, de incorporação e de formação do grupo de direito. É que o art. 137, inciso II, alude à possibilidade do exercício do direito de recesso nos casos dos incisos IV e V do art. 136, (sendo o inciso IV relativo à fusão da companhia, ou sua incorporação em outra, enquanto o inciso $\mathrm{V}$ diz respeito à participação em grupo de sociedades) somente quando as ações de seu titular:

a. não integrarem índices gerais representativos de carteira de ações admitidos à negociação em bolsas de futuros; e

b. sejam de emissão de companhia aberta nas quais menos da metade das ações emitidas estejam em circulação no mercado, entendendo-se por essa expressão - ações em circulação no mercado — "todas as ações da companhia menos as de propriedade do acionista controlador"

Poder-se-ia alegar, em princípio, que a negação do direito de retirada, nas hipóteses mencionadas, decorreria da compreensível presunção de que, existindo elevados níveis de liquidez das ações da companhia, de um lado, ou, paralelamente, havendo alto grau de dispersão de suas ações no mercado, de outro lado, o acionista discordante da decisão da assembléia não-necessitaria do recesso para poder livrarse de seu investimento, que teve a sua natureza abruptamente alterada.

O raciocínio seria de todo válido, deveras - e corresponderia ao que já havíamos destacado linhas atrás - , no sentido de que são muitos os autores como Nelson Eizirik, Paulo Salvador Frontini, Rachel Sztajn, para ficar apenas em alguns 
exemplos, que entendem ocorrer a perda de fundamento para o exercício do direito de recesso, nas companhias abertas, quando o acionista insatisfeito tem a possibilidade de alienar livremente suas ações nas Bolsas de Valores.

Parece não haver dúvida quanto ao raciocínio em tela no que se refere à alínea $a$, do inciso II, do art. 137 da Lei. Com efeito, no caso de ações integrantes de índices gerais representativos de carteira de ações admitidos à negociação em bolsas de futuros, haveria uma espécie de presunção ex lege de que de tais títulos tenham liquidez absolutamente comprovada, inexistindo fundamento axiológico para a manutenção do direito de recesso.

Ocorre, porém, na hipótese da alínea $b$, desse mesmo inciso II, do art. 137, isto é, somente terá direito de retirada o titular de ações "de companhias abertas das quais se encontram em circulação no mercado menos da metade do total das ações por ela emitidas, entendendo-se por ações em circulação no mercado todas as ações da companhia menos as de propriedade do acionista controlador"

O texto está longe de ser um primor de clareza, mas não há dúvida de que não há necessidade de ser versado em matemática para perceber que o critério de dispersão, adotado pela lei, é inequivocamente falho.

Nelson Eizirik ${ }^{69}$ fornece um exemplo extremo. Diz ele:

"Uma companhia com dois acionistas, um com a totalidade das ações votantes (1/3 do capital) e outro com todas as ações preferenciais (2/3 do capital) registra-se na CVM como companhia aberta para emitir publicamente debêntures não conversíveis em ações; em seguida, é incorporada por outra e nega ao preferencialista o direito de recesso, com base em interpretação literal da lei, pois ela é aberta e mais da metade das suas ações não são de propriedade do acionista controlador"

Em seguida, conclui esse autor que:

"Assim, quando a Lei menciona as companhias abertas cujas ações estejam em circulação no mercado, está se referindo, inequivocamente, àquelas 
companhias abertas que se registraram na CVM para procederem à emissão pública de ações.

$O$ critério de dispersão não se relaciona apenas às ações ordinárias, com pleno direito de voto; referindo-se a Lei ao 'total das ações emitidas', fica claro que podem ser ordinárias ou preferenciais, sem direito de voto" (grifos do autor).

Os exemplos poderiam variar indefinidamente. Haveria $n$ hipóteses nas quais o grau de dispersão presumido pelo legislador seria, efetivamente, mínimo. Basta pensar, por exemplo, quer na hipótese de acionistas minoritários ligados ao controlador; quer no caso de o minoritário ser titular de grande número de ações, fazendo com que a metade existente em circulação não-represente a dispersão mínima para que se pudesse falar em alienação livre de ações no mercado.

Enfim, o tema é apaixonante mesmo. Mas é preciso ter cuidado. Como já se disse algures, quando a paixão entra pela porta principal, a sensatez foge pela porta dos fundos...

São Paulo, novembro de 1998.

VIII. Bibliografia

AMENDOLARA, Leslie. Os Direitos dos Acionistas Minoritários, São Paulo, Editora STS Publicações e Serviços Ltda., setembro de 1998.

APROBATO MACHADO, Rubens. Revista de Direito Mercantil n. 82.

ASCARELLI, Tullio. Problemas das Sociedades Anônimas e Direito Comparado, São Paulo, Saraiva, 1969.

AZEVEDO SOUTO, A. Lei das Sociedades por Quotas Anotada, $3^{\mathbf{a}}$ ed., Coimbra, 1941.

BALLANTINE, Henry Winthrop. Ballantine on Corporations, Chicago (Callagnhan and Company), ed. Revista, 1946.

BATALHA, Wilson de Souza Campos. Comentários à Lei das Sociedades Anônimas, Rio de Janeiro, Forense, 1977, v. 2.

BOBBIO, Norberto. De senectute e altri scritti autobiografici, Einaudi.

BRUNETTI, Antonio. Trattato de Diritto delle Società, v. 2, Milão, Giuffrè, 1948. 
BULGARELLI, Waldírio. Fusões, Incorporações e Cisões de Sociedades, São Paulo, Atlas, 1996

CARVAlHOSA, Modesto. Comentários à Lei de Sociedades Anônimas, v. 2, Editora Saraiva, 1997. Revista de Direito Mercantil n. 96.

CINTRA, Maria Lúcia de Araújo. Revista de Direito Mercantil n. 98.

COMPARATO, Fábio Konder. Valor de reembolso no recesso acionário, Revista dos Tribunais, v. 563.

O Poder de Controle na Sociedade Anônima, São Paulo, Editora Revista dos Tribunais, 1975.

COSTA, José Rubens. Sociedades anônimas. Direitos essenciais dos acionistas, Revista Forense 270/567. n. 2, 1980.

DONADIO, Giuseppe. Il recesso del socio, Milão, Giuffrè, 1940.

EIZIRIK, Nelson. Reforma das S.A. \& do Mercado de Capitais, Renovar. 111. Reforma das S.A e Direito de Recesso, Revista de Direito Mercantil n.

FRONTINI, Paulo Salvador. Revista de Direito Mercantil n. 86.

GIAMPICCOLO, Giorgio. La Dechiarazione Recettizia, Milão, Giuffrè, 1959.

LAMY FILHO, Alfredo e BULHÕES PEDREIRA, José Luiz. A Lei das S.A., Rio de Janeiro, Renovar, 1966, v. II, p. 339.

LEÃES, Luis Gastão Paes de Barros. Comentários à Lei das Sociedades Anônimas, Saraiva, 1980, § 214, p. 216.

LOBO, Jorge. Revista dos Tribunais n. 664.

MELLO FRANCO, Vera Helena de. Dissolução parcial e recesso nas sociedades por quotas de responsabilidade limitada. Legitimidade e Procedimento. Critério e Momento de Apuração de Haveres, Revista de Direito Mercantil n. 75.

MENÉNDEZ MENÉNDEZ, Aurelio. Ensayo sobre la evolución actual de la Sociedad Anónima, Cuadernos Civitas, Madrid, Ed. Revista de Occidente, 1974.

MIRANDA, Pontes de. Tratado de Direito Privado, Parte Especial, t. L, São Paulo, Editora Revista dos Tribunais, 1984.

MORITZ, Renata Brandão. Revista de Direito Mercantil n. 101.

PARENTE, Norma Jonssen. Revista de Direito Mercantil n. 97. 
PENTEADO, Mauro Rodrigues. Revista de Direito Mercantil n. 77.

SCHMIDT, Dominique. Les droits de la minorité dans la Société Anonyme, bibliothèque de Droit Commercial, dirigida por R. Houin, t. 21, Sirey.

SZTAJN, Rachel. O direito de recesso nas sociedades comerciais, Revista de Direito Mercantil n. 71, Julho-Setembro/1988.

TAVARES BORBA, José Edwaldo. Direito Societário, $2^{\text {a }}$ ed., Biblioteca Jurídica Freitas Bastos, 1995.

TAVARES GUERREIRO, José Alexandre. Direito de Retirada e Poder de Retratação, Revista de Direito Mercantil n. 44.

TEIXEIRA, Egberto Lacerda. Das Sociedades por Quotas de Responsabilidade Limitada, Max Limonad, 1956.

VIVANTE, Cesare. Trattato di Diritto Commerciale, v. II, Le Società Comerciali, Francesco Vallardi, 1935.

WALD, Arnoldo. Revista de Direito Mercantil ns. 40 e 62.

WANDER BASTOS, Aurélio e EIZIRIK, Nelson. Mercado de Capitais e S/A Jurisprudência, v. 2, Comissão Nacional de Bolsa de Valores. 